\title{
Review Article \\ Current Challenges in Volatile Organic Compounds Analysis as Potential Biomarkers of Cancer
}

\author{
Kamila Schmidt and Ian Podmore \\ Biomedical Science Research Centre, School of Environment and Life Sciences, University of Salford, Manchester M5 4WT, UK \\ Correspondence should be addressed to Kamila Schmidt; k.schmidt@edu.salford.ac.uk
}

Received 25 September 2014; Accepted 10 March 2015

Academic Editor: Ranju Ralhan

Copyright (C) 2015 K. Schmidt and I. Podmore. This is an open access article distributed under the Creative Commons Attribution License, which permits unrestricted use, distribution, and reproduction in any medium, provided the original work is properly cited.

\begin{abstract}
An early diagnosis and appropriate treatment are crucial in reducing mortality among people suffering from cancer. There is a lack of characteristic early clinical symptoms in most forms of cancer, which highlights the importance of investigating new methods for its early detection. One of the most promising methods is the analysis of volatile organic compounds (VOCs). VOCs are a diverse group of carbon-based chemicals that are present in exhaled breath and biofluids and may be collected from the headspace of these matrices. Different patterns of VOCs have been correlated with various diseases, cancer among them. Studies have also shown that cancer cells in vitro produce or consume specific VOCs that can serve as potential biomarkers that differentiate them from noncancerous cells. This review identifies the current challenges in the investigation of VOCs as potential cancer biomarkers, by the critical evaluation of available matrices for the in vivo and in vitro approaches in this field and by comparison of the main extraction and detection techniques that have been applied to date in this area of study. It also summarises complementary in vivo, ex vivo, and in vitro studies conducted to date in order to try to identify volatile biomarkers of cancer.
\end{abstract}

\section{Introduction}

Cancer is the second leading cause of death in the world. It has been estimated that there were 7.6 million fatal cases of cancer (13\% of all deaths) and around 12.4 million new cancer cases in the year 2008 worldwide. Deaths from cancer are forecasted to continue to grow to over 13.1 million in 2030 [1]. The earlier the cancer is detected, the better the chances of the patient recovering are, as appropriate treatment can be applied in time. There are two components of efforts to detect cancer early: early diagnosis and screening. However, there is a lack of characteristic early clinical symptoms in most cancer types that could lead to early detection of the disease [25]. In addition, cancer diagnosis often requires many tests, some of which are invasive surgical procedures. Existing noninvasive methods often have limitations. For example, a new, noninvasive method of lung cancer screening, spiral computer tomography, which has been shown to detect cancer that is curable by surgery, is also accompanied by a risk of exposure to radiation, high false-positive rates, and the possibility of overdiagnosis [6]. This underlines the need for investigation of new methods for the early detection of cancer. In this search all "omics" approaches (genomics, proteomics, and metabolomics) have been applied [7-9]. One of the most promising metabolomic approaches is the analysis of volatile organic compounds (VOCs), which could potentially serve as a safe, noninvasive (at least for breath and some biofluid samples), and specific test for the early detection of different types of cancer.

VOCs are a diverse group of carbon-based chemicals that are classified on the basis of their retention time and boiling point (ranging from $50^{\circ} \mathrm{C}$ to $260^{\circ} \mathrm{C}$ ) [10]. VOCs are emitted from the body in exhaled breath and are present in body specimens such as blood, urine, faeces, and sweat [11-14] and therefore may be collected from the headspace (HS) of these matrices, but also from the HS of cells in vitro [15]. Different patterns of VOCs have been correlated with various diseases and syndromes such as cancer [16], asthma [17], cystic fibrosis [18], diabetes [19], tuberculosis [20], chronic obstructive pulmonary disease [21], heart allograft rejection [22], and irritable bowel syndrome [13]. These correlations are based on the hypothesis that pathological processes, occurring as 
a consequence of disease, can generate new VOCs that the body does not produce during normal physiological processes and/or alter the concentrations of VOCs. These new VOCs, or VOCs that are produced in significantly higher or lower levels than normal, may therefore serve as biomarkers for the assessment or detection of disease.

This review firstly discusses sample matrices that were used in the studies of potential VOC biomarkers of cancer and critically evaluates in vitro and in vivo approaches applied in this field. The investigation of targeted VOCs only (rather than all the VOCs present in a sample) as candidate cancer biomarkers is also discussed. Next this paper reviews complementary in vivo, ex vivo, and in vitro studies conducted to date in order to find volatile biomarkers of cancer. Finally, the main extraction techniques and analytical techniques that have been applied to date in the area of the studies of potential volatile biomarkers of cancer are compared.

\section{Available Approaches for VOCs Collection}

In order to investigate VOCs as cancer biomarkers, analysis of the exhaled breath of patients with different types of cancer has become very popular in recent years [23, 24]. Alternative approaches include the HS analysis of cancer cells, tissues, or body fluids. All sample matrices have their advantages and disadvantages.

\subsection{In Vivo VOCs Collection}

2.1.1. Breath Analysis. Studies have shown that chemical changes in blood due to the presence of cancer are echoed in an alteration of the composition of VOCs in the breath of patients $[25,26]$. Therefore, it is hypothesised that abnormal VOCs produced by cancer cells are discharged via the blood stream into the endobronchial cavity and finally exhaled with breath [27].

Breath analysis, compared to blood and urine tests, is noninvasive and a sample may be easily collected at any point and in varying quantities, which makes it easy to repeat [28]. Furthermore, it does not require special storage conditions or any further work after collection. In addition, the breath matrix is a less complex mixture than urine or blood. There are approximately $200 \mathrm{VOCs}$ present in a breath sample. However, they are not the same for each individual. Around 3500 different VOCs were detected in the breath of 50 people, and only 27 were found in the samples of all the subjects. Approximately half of these 3500 compounds are of possible endogenous and half of possible exogenous origin [29]. New volatile compounds are still being identified. Only compounds produced inside the body can be considered as biomarkers, which is problematic as the origin of most volatile metabolites is still unknown or remains the subject of speculation $[27,30]$. The presence of both endoand exogenous VOCs in exhaled air is one of the biggest limitations of breath analysis. Another is qualitative and quantitative interindividual and intraindividual variability. The majority of the detected VOCs were found only once in one particular individual [29] and the patterns of VOCs may change according to food consumption, smoking, gender, age, and so forth $[31,32]$.

There are different opinions about how detailed knowledge is required for a successful breath diagnostic test. Some argue that there is no need to know the origin of a volatile compound biomarker, as long as it can be used to distinguish disease from a healthy state $[33,34]$. Others simultaneously measure exhaled and inspired air since the environmental contaminant VOCs may be incorrectly assigned as endogenous compounds [35]. Finally, the last approach requires knowledge about the metabolic pathway of the compound, as well as about normal concentration ranges of a compound in relation to interindividual variability, before including it into the predictive model of the disease [36].

Moreover, since the beginning of breath analysis in the 1970s [11] standardisation and reproducibility of the sample collection method have been an issue which has resulted in the variability of quantitative information $[37,38]$. Standardisation is easier to achieve for serum or urine than for breath collection [37], which is a big advantage of these matrices. Furthermore, equipment for exhaled breath collection is relatively expensive and may thus not be easy to apply widely [23]. The importance (limitations and/or applications) of breath analysis has been described previously [30, 31, 3742].

2.1.2. Breath Analysis versus Body Fluids. Although VOCs detected in blood and urine are "in the body" analytes, it still does not mean they are of endogenous origin. Some inhaled VOCs may bind to or dissolve in blood [43] and be stored in body compartments and later excreted through urine [44]. In addition, it is not known which volatile compounds are produced or consumed by tumour cells as they may also be generated (or consumed) by noncancerous cells (such as surrounding tissue cells or other regions of the body) $[45,46]$, immune-competent cells [47], human symbiotic bacteria [48, 49], and infectious pathogens [50, 51]. Furthermore, VOC patterns differ between individuals because of uncontrolled variables such as genetic differences, environmental settings, diet, drug ingestion, and smoking [31, 32], which makes VOC analysis a challenge regardless of the matrix used. Nevertheless, there is growing evidence that VOCs that are potentially clinically relevant may be found in breath and other matrices. Dogs were reported to discriminate between patients with or without cancer by sniffing skin, blood, urine, or breath samples of cancer patients, which suggests that characteristic VOC signatures of cancer exist [52-57]. Sensor mice were also trained to distinguish mice with experimentally-induced cancer from mice without it [58].

Blood was used as a matrix for VOC collection in a number of studies of lung cancer $[26,59]$, childhood forms of cancer [60], and liver cancer [61]. The disadvantages of blood as a matrix include invasiveness, and careful handling and further work after collection as temperature and $\mathrm{pH}$ changes can alter VOC profile [37, 62]. Moreover, there are difficulties in the collection of arterial blood. When there is a necessity to collect many of such samples, breath analysis would be a better alternative, especially as it closely mirrors the arterial concentrations of metabolites [23]. 
In theory, the composition of volatile compounds in breath is related to the composition of these compounds in blood $[23,26]$. This needs to be addressed in studies comparing VOC composition in blood and breath samples. Such an investigation concerning cancer was performed by Deng et al. [26]. The study showed that 23 VOCs found in blood were also present in the exhaled breath of lung cancer patients. Therefore, there are characteristic compounds which identify cancer presence. Among these 23, hexanal and heptanal were detected only in cancerous blood and breath samples and were not found in controls. However, more study is required to compare VOC patterns in both matrices, where ideally the blood and breath samples from the same patient would be investigated.

Many studies have also investigated volatile biomarkers in urine samples of patients with various cancers such as breast [63], gastroesophageal [64], lung [65], leukaemia, colorectal, lymphoma [44], childhood leukaemia [60], and bladder cancer [66]. In addition to its noninvasive nature and availability in large volumes, urine as a matrix for VOC analysis also has an advantage over other biofluids in that analytes are concentrated by the kidney before being excreted from the body. In addition, when compared to blood, the use of urine usually results in better detection limits as matrix effects may interfere with the release of the VOCs into HS in blood sampling [67]. On the other hand, VOCs in urine may be affected by the drugs administered to a patient, and therefore the metabolic products of particular changes must be known as well as determining their effect on the VOCs produced [66].

\subsection{In Vitro VOCs Collection. The investigation of VOCs} produced by cancerous cells in the microenvironment as the source of biomarkers should hypothetically help with the dilemma of their origin, as advantages of in vitro studies over other matrices include easier control of experimental variables and more easily interpreted results, due to the absence of factors such as gender, age, and interindividual variation (with the exception of primary cell cultures) [68]. They also offer lower cost and better reproducibility. However, this matrix still does not guarantee that the collected VOCs are of endogenous origin. They may not be produced by cancer cells themselves and may instead come from other sources such as culture vessels, extraction devices, and the sampling environment $[69,70]$.

The cell metabolome is comprised of the endometabolome, which is represented by all metabolites inside the cell, and the exometabolome, which is made up of all metabolites present in the extracellular cell culture medium. The profile of these metabolites in the surrounding medium depends on the uptake and extraction of the compounds by the cells and reflects their metabolic activity via their response to experimental variables. In vitro studies aiming to find potential volatile markers of cancer essentially apply the extracellular metabolite investigative approach. Endometabolomic studies require cell disruption, and then concentration of the extracted compounds (mainly with the use of evaporation). VOCs could be easily lost during these steps [68].
A number of studies have been performed to investigate potential VOC cancer biomarkers in vitro in different types of cancer and using different techniques, and in all of them there were differences observed in the composition of volatile metabolites produced by cancer and normal cells [69-81].

However, some studies found differences in VOC levels, or VOCs produced, between not only different cell lines of the same cancer (showing that their metabolic pathways are different) but also the same cell line $[15,75,79-82]$. While the first observation may be explained by genetic and phenotypic differences and the fact that each cell line is representative of only a small part of a primary tumour, the reasons for the second are unclear $[15,80]$. It may be due to the cell line being subcultured a different number of times. The study of Sponring et al. [72] showed the possibility of a change of released volatile metabolites with increasing passage number. Cells should not be subcultured for a long period of time to ensure they have not mutated, as mutation could cause them to no longer reflect the properties of the tumour of origin. The fact that there were significant experimental differences in many studies between the cell cultures that had been subcultured a low number of times, compared to those that had been subcultured a high number of times, and the fact that there were studies conducted on cross contaminated cell lines make a compelling case for the use of certified cell lines with defined passage numbers [83].

In the cell/tissue HS analysis of VOCs there are also differences in the techniques used, and a lack of standardisation and normalisation of the data, even when the same technique is used, which may influence variations in VOC patterns between different studies. The aspects to be considered (apart from the technique used) (Table 1) in terms of in vitro studies of VOCs include the analysis of different matrices, the use of different cell culture media, the period of cell cultivation, the different cell density, the different cell controls used, the different statistical methods used, and finally the differing methodology.

Length of incubation periods and differing types of culture (in monolayer, matrix immobilized cultures, or 3D cultures) as well as supplementation of cell culture medium have been shown to have an influence on the composition of the VOCs in the samples [79, 81, 84-86]. Drug addition also has been shown to change the pattern of VOCs produced by A549 cells in vitro, highlighting the possibility of finding biomarkers of apoptosis and necrosis induced by drugs [87].

The main matrices analysed to study VOCs generated by cells are (i) HS of the cell-free culture medium of a target cell and (ii) HS of the medium still containing the cells. The HS of cell lysate (preconcentrated supernatant of the lysed cells) is another matrix employed, but has only been used in a few studies, solely for the determination of targeted VOCs produced by cancer cells treated with drugs (Table 1).

There are some substantial differences in terms of the extraction procedure details for the main two matrices. For example, analysis of culture media with cells usually takes place at $37^{\circ} \mathrm{C}$ (physiological conditions), while analysis of media only may employ a higher temperature. Also, the efficiency of analysis of media only samples can be improved by the addition of salts or by a change of $\mathrm{pH}$, while such 
TABLE 1: Analytical technique used, cancer cell lines studied, and type of matrix and control used in in vitro studies aiming to investigate VOCs as potential cancer biomarkers. DNTD: dynamic needle trap device; ESI: electrospray ionisation; GC-MS: gas chromatography-mass spectrometry; MC: multicolumn; Mm: metastatic melanoma cell; ns: not specified; NSCLC: non-small-cell lung cancer; p: preconcentration; PT: purge and trap; PTR-MS: proton transfer reaction-mass spectrometry; RPG: radial growth cell; SCLC: small-cell lung cancer; SIFT-MS: selected ion flow tube-mass spectrometry; SPME: solid phase microextraction; VPG: vertical growth cell.

\begin{tabular}{|c|c|c|c|c|c|}
\hline $\begin{array}{l}\text { Analytical technique } \\
\text { used }\end{array}$ & Cancer type & Cell lines studied & Control & Type of matrix & Reference \\
\hline SPME-GC-MS & Lung cancer & A549 & $\begin{array}{l}\text { OUS11 and WI-38 VA } \\
13\end{array}$ & $\begin{array}{c}\text { Cell-free culture } \\
\text { medium }\end{array}$ & [79] \\
\hline SPME-GC-MS & Skin cancer & $\begin{array}{c}\text { RPG: M35, WM3211, } \\
\text { and Sbcl2 } \\
\text { VPG: WM115 and } \\
\text { WM983A } \\
\text { Mm: WM983B and } \\
\text { WM1158 }\end{array}$ & $\begin{array}{l}\text { FOM136, FOM191, } \\
\text { and pure medium }\end{array}$ & $\begin{array}{l}\text { Cell-free culture } \\
\text { medium }\end{array}$ & [70] \\
\hline SPME-GC-MS & Lung cancer & $\begin{array}{l}\text { A549, SK-MEM-1, } \\
\text { and NCIH } 446\end{array}$ & BEAS2B & $\begin{array}{l}\text { Cell-free culture } \\
\text { medium }\end{array}$ & [76] \\
\hline SPME-GC-MS & Colon cancer & SW1116 and SW480 & $\begin{array}{l}\text { NCM460, pure } \\
\text { medium }\end{array}$ & $\begin{array}{c}\text { Culture medium with } \\
\text { cells }\end{array}$ & {$[69]$} \\
\hline SPME-GC-MS & Lung cancer & $\begin{array}{l}\text { Primary lung cancer } \\
\text { cells }\end{array}$ & $\begin{array}{l}\text { Primary normal cells } \\
\text { (human lung cells, } \\
\text { lipocytes, osteogenic } \\
\text { cells, and rat taste bud } \\
\text { cells) }\end{array}$ & $\begin{array}{l}\text { Cell-free culture } \\
\text { medium }\end{array}$ & {$[78]$} \\
\hline SPME-GC-MS & Lung cancer & A549 & Pure medium & $\begin{array}{c}\text { Culture medium with } \\
\text { cells }\end{array}$ & [87] \\
\hline $\begin{array}{l}\text { Nanosensors (quartz } \\
\text { microbalances), } \\
\text { SPME-GC-MS } \\
\end{array}$ & $\begin{array}{c}\text { Melanoma, } \\
\text { synovial sarcoma, } \\
\text { and thyroid cancer }\end{array}$ & Primary cells & Pure medium & $\begin{array}{l}\text { Culture medium with } \\
\text { cells }\end{array}$ & {$[154]$} \\
\hline $\begin{array}{l}\text { Ultra II SKC-GC-MS, } \\
\text { nanosensors (gold } \\
\text { nanoparticles) }\end{array}$ & Lung cancer & $\begin{array}{c}\text { NSCLC: A549, } \\
\text { Calu-3, H1650, } \\
\text { H4006, H1435, H820, } \\
\text { and H1975 }\end{array}$ & Pure medium & $\begin{array}{l}\text { Culture medium with } \\
\text { cells }\end{array}$ & {$[123]$} \\
\hline $\begin{array}{l}\text { Ultra II SKC-GC-MS, } \\
\text { nanosensors (gold } \\
\text { nanoparticles) }\end{array}$ & Lung cancer & $\begin{array}{c}\text { NSCLC: A549, } \\
\text { Calu-3, H1650, } \\
\text { H4006, H1435, H820, } \\
\text { H1975, H2009, } \\
\text { HCC95, HCC15, } \\
\text { H226, and NE18 } \\
\text { SCLC: H774, H69, } \\
\text { H187, and H526 }\end{array}$ & IBE, pure medium & $\begin{array}{l}\text { Culture medium with } \\
\text { cells }\end{array}$ & {$[73]$} \\
\hline $\begin{array}{l}\text { ORBOTM } 420 \text { Tenax } \\
\text { TA sorption } \\
\text { tubes-GC-MS, } \\
\text { nanosensors (gold } \\
\text { nanoparticles; single } \\
\text { walled carbon } \\
\text { nanotubes) }\end{array}$ & Liver cancer & $\begin{array}{c}\text { MHCC97-H, } \\
\text { MHCC97-L, HepG2, } \\
\text { SMMC-7721, and } \\
\text { BEL-7402 }\end{array}$ & L-02 & $\begin{array}{l}\text { Culture medium with } \\
\text { cells }\end{array}$ & {$[71]$} \\
\hline PT-GC-MS & Lung cancer & Calu-1 & Pure medium & $\begin{array}{c}\text { Culture medium with } \\
\text { cells }\end{array}$ & [15] \\
\hline PT-GC-MS & Lung cancer & NCI-H2087 & Pure medium & $\begin{array}{c}\text { Culture medium with } \\
\text { cells }\end{array}$ & {$[72]$} \\
\hline PT-GC-MS & Lung cancer & A549 & $\begin{array}{l}\text { HBEpC, hFB, and } \\
\text { pure medium }\end{array}$ & $\begin{array}{c}\text { Culture medium with } \\
\text { cells }\end{array}$ & {$[80]$} \\
\hline DNTD-GC-MS & Liver cancer & HepG2 & Pure medium & $\begin{array}{c}\text { Culture medium with } \\
\text { cells }\end{array}$ & {$[122]$} \\
\hline
\end{tabular}


TABle 1: Continued.

\begin{tabular}{|c|c|c|c|c|c|}
\hline $\begin{array}{l}\text { Analytical technique } \\
\text { used }\end{array}$ & Cancer type & Cell lines studied & Control & Type of matrix & Reference \\
\hline $\begin{array}{l}\text { pMC-GC-MS } \\
\text { (p: cryogenic) }\end{array}$ & Leukaemia & HL60 & Pure medium & $\begin{array}{l}\text { Culture medium with } \\
\text { cells }\end{array}$ & {$[125]$} \\
\hline SIFT-MS & Breast cancer & $\begin{array}{l}\text { MCF-7 and } \\
\text { MCF-7Adr }\end{array}$ & ns & Cell lysate & {$[155]$} \\
\hline $\begin{array}{l}\text { p-SIFT-MS } \\
\text { (p: distillation) }\end{array}$ & $\begin{array}{l}\text { Breast, leukaemia, } \\
\text { cervical, and } \\
\text { prostate cancer }\end{array}$ & $\begin{array}{l}\text { MCF-7, MCF-7Adr, } \\
\text { HeLa S3, K562, } \\
\text { LNCaP, and DU-145 }\end{array}$ & $\begin{array}{l}\text { Solid residue left after } \\
\text { centrifugation }\end{array}$ & Cell lysate & [156] \\
\hline p-SIFT-MS & Breast cancer & $\begin{array}{l}\text { MCF-7 and } \\
\text { MCF-7Adr }\end{array}$ & $\begin{array}{l}\text { Solid residue left after } \\
\text { centrifugation }\end{array}$ & Cell lysate & [157] \\
\hline SIFT-MS & Lung cancer & CALU1 & NL20, pure medium & Medium with cells & {$[81]$} \\
\hline PTR-MS & Lung cancer & A549 and EPLC & $\begin{array}{l}\text { hTERT-RPE1, } \\
\text { BEAS2B, and pure } \\
\text { medium }\end{array}$ & Medium with cells & {$[74]$} \\
\hline SIFT-MS & Lung cancer & Calul and SK-MEM-1 & Pure medium & Medium with cells & {$[82]$} \\
\hline SIFT-MS & Lung cancer & Calu-1 & $\begin{array}{l}\text { NL20, 35FL121 Tel+, } \\
\text { and pure medium }\end{array}$ & Medium with cells & {$[75]$} \\
\hline Online (ESI)MS & Breast cancer & $\begin{array}{l}\text { T47D, SKBR-3, and } \\
\text { MDA-MB-231 }\end{array}$ & HMLE & $\begin{array}{l}\text { Cell-free culture } \\
\text { medium }\end{array}$ & {$[77]$} \\
\hline
\end{tabular}

changes are not possible when cells are present. On the other hand, the analysis of media with cells ensures that no VOCs are lost during storage. Finally, the vessel used for cell culture is of great importance. Some researchers use glass vials as they have very limited release of volatile chemicals (other materials such as standard plastic flasks for cell culture release plasticizers generating additional peaks) $[69,88]$.

2.3. In Vitro versus In Vivo Analysis. A recent review by Kalluri et al. [89] makes a case that the studies in vivo and in vitro, investigating VOCs as potential biomarkers of cancer, have poor correlations (specifically studies of lung cancer and exhaled breath as a sample matrix). They postulate that the overlap between VOCs found in the exhaled breath of lung cancer patients and compounds produced by lung cancer cells in vitro (approximately one-quarter being common to both matrices) is not sufficient at the moment for in vitro culture to be a good model for the VOCs present in exhaled breath. The authors propose that it could be due to cell cultivation in hyperoxic conditions (atmospheric oxygen concentration) emphasising it as a potential limitation of the in vitro studies performed to date. Tumours have been shown to grow in hypoxic (oxygen depleted) or anoxic (oxygen absent) conditions as opposed to normal tissues [90]. Cellular oxidative stress would lead to the production of different VOCs by cells in comparison to hyperoxic cell culture conditions. Studies comparing the patterns of VOCs present in the HS of cells cultured in hyperoxic and hypoxic conditions are needed to address this potential limitation of in vitro approach.

However, another issue related to cell culture conditions could also result in the different VOCs present in the HS of cell culture and samples taken from the patient. Standard 2D cell culture conditions may have a great impact on the cell metabolic behaviour, thereby losing accuracy when looking for biomarkers when compared to $3 \mathrm{D}$ culture that better mimics the growth of the tumour [81].

The poor correlation between in vivo and in vitro studies may also arise from exogenous VOCs being included in the predictive models of cancer [30], different extraction and detection techniques used in different studies, different experimental design, and in general a relatively lower number of in vitro studies performed to date, in comparison to the VOC studies of breath samples and biofluids. In addition, studies which show that the VOC patterns do not change after tumour removal imply that some VOCs may be biomarkers of the risk of cancer developing, rather than being indicative of the presence of a tumour (see Section 2.4 for further discussion). Also it is important to remember that there is very little known about the complexity of the transmission mechanisms of the VOCs produced by tumour cells in the body and found in breath or biofluids. An excellent review of lung cancer VOC studies, which describes possible biological pathways of lung cancer VOCs identified from different matrices, shows that this is a main challenge to date for cancer VOC analysis [27]. Therefore, the composition of VOCs found in the samples from the patients and VOCs detected in the HS of cultured cells cannot be expected to be the same. However the studies that have been performed to date in order to find potential volatile biomarkers of cancer show that the VOCs common to all matrices exist, regardless of the potential limitations of the in vivo and in vitro approaches discussed above.

2.4. Complementary Studies In Vivo, Ex Vivo, and In Vitro. Without doubt, there is a need for a simultaneous investigation of the correlation of the VOC pattern in exhaled breath (and other sample types) collected from a patient and an in vitro and/or ex vivo analysis of the VOCs produced by the cancer cells or emitted from the cancer tissues (ideally of the 
same patient). This approach eliminates analytical technique and, in the case of the samples coming from the same patient, factors such as gender, age, and interindividual variation as the sources of possible differences in VOC patterns between in vivo, in vitro, and ex vivo samples.

Some studies already have been conducted specifically in order to simultaneously compare VOCs produced by cancer cells in vitro and ex vivo to the ones found in breath from the patient.

The study of Chen et al. [78] aimed to compare VOCs produced by four types of primary lung cancer cells to VOCs found in cancer breath samples. In this study, 11 VOCs were found in breath samples and chosen for principal component analysis in order to discriminate cancer patients from healthy controls, and two compounds were shared with lung cancer cells excised from the patients (namely, isoprene and undecane) [78].

Another study compared volatile metabolites determined in a culture medium of lung cancer cell line A549 to the VOC composition in the HS of urine of mice implanted with these cells. There were seven VOCs found at significantly higher levels in both sample types when compared to normal cancer cell lines (dimethyl succinate, 2-pentanone, phenol, 2-methylpyrazine, 2-hexanone, 2-butanone, and acetophenone) [79].

The study performed by Buszewski et al. [28] involved quantitative VOC measurement in the HS of healthy and lung cancer tissues and comparison of these results to the ones obtained from the breath samples of the healthy individuals and lung cancer patients. 27 VOCs were detected in the air above cancerous tissues, cutting down the number of potential biomarkers that need to be considered when breath samples are analysed. 22 of the same compounds (mainly alcohols, aldehydes, ketones, and aromatic and aliphatic hydrocarbons) were found in the breath samples, just as in the HS of lung tissues. Quantitative analysis of VOCs emitted by lung cancer tissues showed higher levels of ethanol, acetone, acetonitrile, 1-propanol, 2-propanol, carbon disulfide, dimethyl sulfide, 2-butanone, and 2-pentanone when compared to control lung tissues. The same compounds were detected in increased concentrations in the breath samples of patients suffering from lung cancer when compared to healthy controls. Some of them were detected in the HS of cancer cells in previous studies (Table 2).

The exhaled breath of lung cancer patients was compared not only to the breath of healthy controls, but also to the compounds detected in the HS of lung tissues (cancerous and healthy), again in the recent study by Filipiak et al. [91]. They detected 39 VOCs in both types of samples: tissue specimens, and exhaled breath (with different occurrence ranging from 8 to $100 \%)$. Over half of the detected compounds were previously reported in the HS of cancer cells in vitro in different studies (Table 2). Although approximately half of the VOCs in the breath samples had negative alveolar gradient (alveolar gradient: abundance in breath minus abundance in the air), suggesting their exogenous origin, these findings show common VOCs in all three sample types. Out of 39 detected, they found 30 VOCs at higher concentrations in cancerous lung tissue, when compared to the healthy tissue controls. Six were elevated at the chosen level of significance: ethanol, pyridine, 4-methylheptane, acetaldehyde, n-octane in the HS of lung cancer tissues, and n-hexanone in the HS of healthy tissues. Ethanol and octane were also found at significantly higher levels in the breath of lung cancer patients. What is more, these compounds were previously detected in the HS of lung cancer cells in vitro. Acetaldehyde and 4-methylheptane were also found in the HS of cultured cancer cells. Other VOCs found in higher levels in the cancerous lung tissue (but not at significant levels) such as 2-methyl-1-pentene, 4-methyloctane, 2,4-dimethylheptane, hexane, and acetic acid were also previously detected in the HS of different cancer cell lines (Table 2).

Poli et al. [92, 93] in their unique study measured VOC concentrations in the breath of lung cancer patients before and a month and three years after the excision of a tumour. In the study, they analysed 12 VOCs that were found in higher concentrations in the breath of cancer patients than in the breath of healthy controls before the surgery. They compared the concentrations of these analytes to the VOC levels found in cancerous and healthy lung tissue collected during the surgery. Collection and storage issues allowed for analysis only of aromatic hydrocarbons in the tissue specimens. Six aromatic VOCs were found to be common to the exhaled breath and tissue samples (benzene, ethylbenzene, trimethylbenzene, toluene, styrene, and xylenes). Their levels (except for xylenes) were significantly higher in cancerous tissue than in healthy tissue. Ethylbenzene, xylenes, and styrene were compounds detected in the HS of lung cancer cells in previous studies (Table 2). Interestingly, no differences in the levels of 11 of the VOCs (isoprene being the exception) were found between the breath collected before and one month after the tumour removal. Similar outcomes were obtained by Phillips et al. [94] who did not observe any changes in the VOC profiles in the breath of most lung cancer patients before and after surgery. In Poli et al.s study, three years after surgery, the levels of some of these compounds had changed (decreased for isoprene and benzene, increased for pentane, toluene, and ethyl benzene) [92].

The findings of both Poli et al.s and Phillips et al's studies imply that changes in the VOC patterns are not biomarkers of lung cancer presence but rather are epiphenomenon of the disease development. In fact Phillips et al. [94, 95] proposed an upstream hypothesis which may explain these results as opposed to a downstream hypothesis. In the latter, the presence of the disease causes the altered patterns of VOCs in breath samples. In Phillips et al.s pathophysiologic model, altered VOC profiles in the breath of the person suffering from lung cancer and the presence of the disease itself are somewhat independent. A person carrying high-risk genotypes due to exposure to carcinogens will have induced activity of the enzymes catabolising VOCs. The patterns of the volatile metabolites may therefore be altered before the appearance of the tumour. Excision of the tumour does not eliminate the induced activity of the enzymes. However, the fact that common VOCs were found in the breath, the HS of lung tissues of cancer patients, and the HS of cancer cells grown in vitro, in addition to the fact that the levels of some compounds changed after a longer period following an 
TABLE 2: Volatile organic compounds detected in both the exhaled breath of lung cancer patients and the HS of lung cancer tissues in studies that simultaneously investigated VOCs ex vivo and in vivo. Only VOCs that have also been previously detected in the HS of cancer cells in vitro in other studies are listed.

\begin{tabular}{|c|c|c|c|}
\hline Class & Volatile organic compound & Reference & In vitro study reference \\
\hline \multirow{3}{*}{ Alkanes } & Pentane & {$[28]$} & {$[72]$} \\
\hline & Hexane & {$[28,91]$} & {$[72]$} \\
\hline & Octane & [91] & {$[80]$} \\
\hline \multirow{4}{*}{ Branched alkanes } & 2-Methylpentane & {$[28,91]$} & {$[72]$} \\
\hline & 3-Methylpentane & {$[28]$} & {$[72]$} \\
\hline & 2,3,4-Trimethylpentane & [91] & {$[72]$} \\
\hline & 4-Methyloctane & [91] & {$[15,72]$} \\
\hline \multirow{2}{*}{ Alkenes } & 2-Methyl-1-pentene & [91] & {$[80]$} \\
\hline & 2,4-Dimethyl-1-heptene & [91] & {$[72,79,80]$} \\
\hline \multirow{2}{*}{ Alcohols } & Ethanol & {$[28,91]$} & {$[79,80,82]$} \\
\hline & 1-Propanol & {$[28]$} & {$[72]$} \\
\hline \multirow{7}{*}{ Aldehydes } & Acetaldehyde & {$[28,91]$} & {$[15,72,74,75,81,82,125]$} \\
\hline & Acrolein & [91] & {$[15]$} \\
\hline & Hexanal & [91] & {$[15,72,74,80,122,125]$} \\
\hline & 3-Methylbutanal & [91] & {$[72,122]$} \\
\hline & 2-Methylpropanal & [91] & {$[15,72,80,122]$} \\
\hline & 2-Methylbutanal & [91] & {$[72,122]$} \\
\hline & Benzaldehyde & {$[28,91]$} & {$[15,69,70,79,122]$} \\
\hline \multirow{5}{*}{ Ketones } & Acetone & {$[28,91]$} & {$[70,80]$} \\
\hline & 2-Butanone & {$[28,91]$} & {$[15,72,79]$} \\
\hline & 2-Pentanone & {$[28,91]$} & {$[79,80,122]$} \\
\hline & 2-Hexanone & [91] & {$[79]$} \\
\hline & 6-Methyl-5-hepten-2-one & [91] & {$[70]$} \\
\hline Carboxylic acids & Acetic acid & [91] & {$[82,123]$} \\
\hline Ethers & Diethyl ether & {$[28]$} & {$[79]$} \\
\hline Pyrroles & Pyrrole & {$[91]$} & {$[79,80]$} \\
\hline Nitriles & Acetonitrile & {$[28,91]$} & {$[15,79,122]$} \\
\hline \multirow{4}{*}{ Aromatics } & o-Xylene & {$[92]$} & {$[79,123]$} \\
\hline & p-Xylene & {$[28,92]$} & {$[123]$} \\
\hline & Ethylbenzene & {$[28,92]$} & {$[123]$} \\
\hline & Styrene & {$[92]$} & {$[79,123]$} \\
\hline
\end{tabular}

operation to remove a tumour, implies that at least some of the VOCs are produced by the tumour per se and may not be attributable to genetic predispositions. Further studies are required to confirm any of these hypotheses.

2.5. Analysis of Targeted VOCs. A different approach to the issue of the possible exogenous origin of proposed VOC biomarkers focuses on the detection of aldehydes $[12,59$, $65,96]$ or hydrocarbons [97-99] only as markers of cancer. Studies proved that oxidative stress is one of the main sources of developing cancer via the overproduction of reactive oxygen species and nitrogen species resulting in mutations [100]. Some aldehydes are known to be related to oxidative stress as they are products of lipid peroxidation, but the exact mechanism of their presence in breath and body fluids is not known [27, 101, 102]. The same mechanism underlies the emission of saturated hydrocarbons in the body. They are products of lipid peroxidation of polyunsaturated fatty acids (PUFA) [27]. This process does not involve branched hydrocarbons as there are no branched polyunsaturated fatty acids in the body [103], nor does it appear to involve methylated alkanes as there is not enough data to support their origin from lipid peroxidation [104]. As aldehydes are highly reactive and can easily decompose or react while the sample is prepared for analysis or storage, a chemical derivatization has been introduced [96]. One of the most common derivatization methods for aldehyde determination is the reaction of aliphatic aldehydes with PFBHA O- $(2,3,4,5,6$ pentafluorophenyl)methylhydroxylamine hydrochloride to produce stable oximes [105]. Different studies that employed different techniques of extraction demonstrated this as an effective method for aldehyde analysis in various matrices $[12,60,106-108]$.

Higher concentrations of straight C3-C9 aldehydes [32, $65,96,106,108]$, as well as some unbranched hydrocarbons $[28,93,97,99]$, were identified among VOCs in cancerous 
breath, blood, and urine matrices in many studies. What is more, some of these VOCs are the analytes that have been found common to the HS of cancer cells in vitro and exhaled breath of lung cancer patients [89].

\section{Techniques of Extraction and Detection for Investigation of VOCs as Potential Cancer Biomarkers}

3.1. Extraction Techniques. Concentrations of most of the VOCs present in biological matrices are low: in the $\mathrm{nmol}^{-1}-\mathrm{pmol}^{-1}$ (ppb-ppt) range in exhaled human breath and in the $\mu \mathrm{mol}^{-1}-\mathrm{nmol}^{-1}$ (ppm-ppb) range in blood and urine $[12,35,37,60]$. In addition, VOCs are analytes of interest to be extracted from complex mixtures. Therefore, prior to the assay, a preconcentration step is required, which is the most labour-intensive part of the analysis and is the primary source of errors influencing the reliability and accuracy of analysis [109]. Increased reproducibility and elimination of interfering compounds can be achieved by minimising the number of steps. The ideal properties of a sample-preparation device include simplicity, high extraction capacity and selectivity, efficiency, speed, possible automation and miniaturization, compatibility with a range of separation and detection methods, and safety in use for the operator and environment $[110,111]$. Microextraction methods employ some of these features the best, when compared to the traditional sampling techniques of liquid-liquid extraction and solid-phase extraction. Solid-phase microextraction (SPME) in particular became very popular due to its simplicity and lack of solvent use and the fact that it has been automated and is compatible with GC-MS and LC-MS [112].

Purge and trap (PT) and solid phase microextraction (SPME) are the two main extraction techniques used to date for the collection of VOCs in both in vivo and in vitro studies of potential cancer biomarkers. In PT (also called dynamic headspace extraction) the gas sample is purged through the sorbent trap by an inert gas and the VOCs are retained on the surface of the trap (Figure 1). Next they are thermally desorbed with the use of an online thermal desorption (TD) device or extracted with small amounts of solvents (liquid desorption: LD). Sorbent traps are adsorption materials contained in a small tube. The most commonly used sorbent traps for the analysis of VOCs employ charcoal (e.g., Carbotrap) or porous polymer (e.g., Tenax) as a trapping material with varying degrees of selectivity. TD may cause degradation reactions of sensitive compounds and column degradation, as some sorbents have a high affinity to water [113]. There are various techniques for water removal in PT such as the use of drying gas, a water condenser, or an additional adsorption trap [114]. LD is a milder technique, so it does not cause degradation of sensitive VOCs; however it is less sensitive [113]. In studies of potential VOC cancer biomarkers only TD-PT has been employed (with cryofocusing to enhance resolution) (e.g., [35, 80]).

SPME is an extraction technique where an extraction phase is dispersed on a fine rod made of fused silica, Stableflex, or metal alloy. The SPME device consists of two

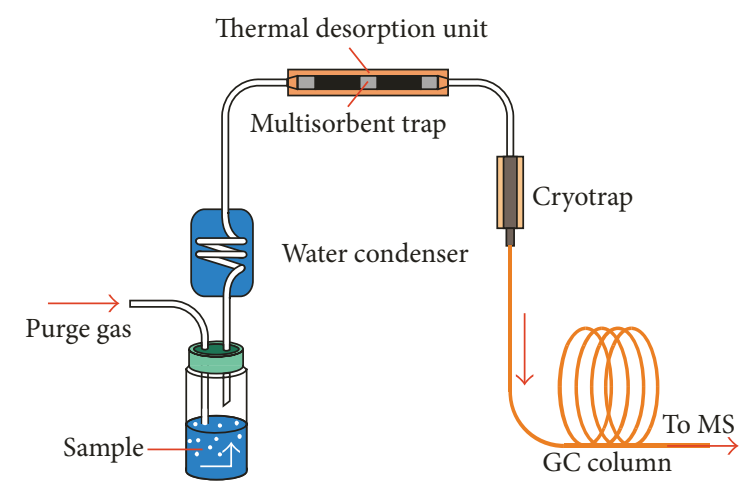

FIgURE 1: Diagram of analysis with online purge and trap-gas chromatography-mass spectrometry (PT-GC-MS).

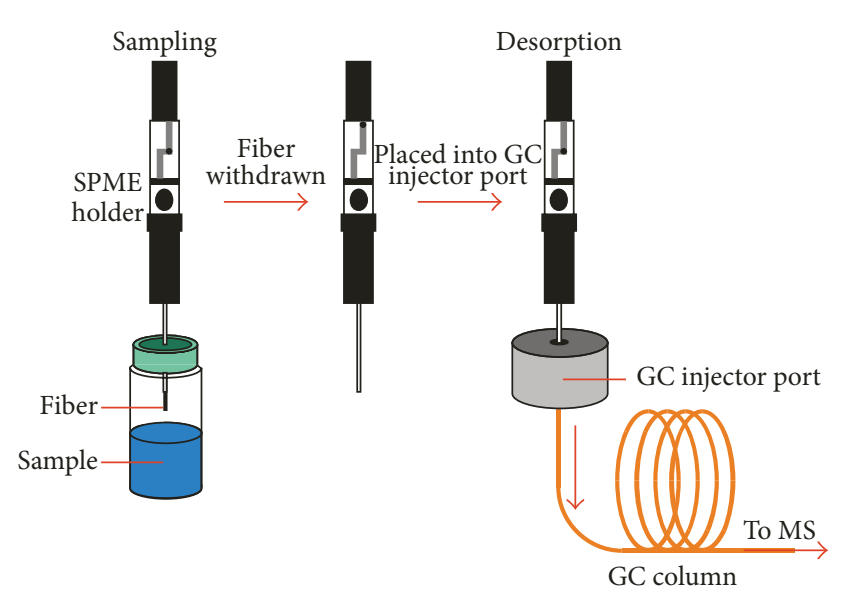

FIGURE 2: Diagram of analysis with solid phase microextraction-gas chromatography-mass spectrometry (SPME-GC-MS).

parts: the holder and, contained in it, the fiber assembly. There are two versions of the SPME holder: one for manual use and one for use with autosamplers or with a high performance liquid chromatography-SPME (HPLC-SPME) interface. The fiber unit consists of a fiber core attached via a hub to a stainless steel guiding rod, which is contained in a hollowed needle that pierces a septum. The fiber is withdrawn from this needle when sampling and the needle is removed when not in use (Figure 2). The fiber core is 1 or $2 \mathrm{~cm}$ long and is coated with stationary phase. The fiber is immersed in the liquid sample in the case of direct immersion (DISPME) or suspended in the HS above the sample (HS-SPME). During extraction, sample molecules preferentially partition from matrix to stationary phase as a result of adsorption or absorption. In the adsorption process the analytes remain on the surface of the trapping material due to chemical bonding. In the absorption process, the analytes are dissolved into the bulk of a liquid phase (e.g., PDMS) [115]. After sampling, the analytes are thermally desorbed in the injector port with no use of solvents (Figure 2).

There are several commercially available SPME fibers for sampling a wide range of compounds that employ four polymers as stationary phases: divinylbenzene (DVB), 
polydimethylsiloxane (PDMS), polyacrylate (PA), and polyethyleneglycol (PEG). They are used on their own as a coat (available in different thicknesses) or in combination blended with carboxen (CAR). The coatings differ by polarity (polar, bipolar, and nonpolar) and extraction mechanism (absorbent or adsorbent). The choice of fiber coating depends on the polarity of analytes and their molecular weight. Previous analyses of VOCs as biomarkers of cancer has been performed in most cases with the use of a $75 \mu \mathrm{m}$ CAR/PDMS coating regardless of the type of matrix tested. Its use is justified, as the fiber was initially developed for the extraction of volatile and small compounds [116].

In comparison, a sorbent trap is an exhaustive extraction technique, due to chemical reactions between the stationary phase and the analytes, whereas SPME is a nonexhaustive (passive) equilibrium technique where the amounts of VOCs extracted are controlled by the series of distribution constants between the gaseous, liquid, and coating phases. Sorbent trapping is based on an adsorption process. SPME, depending on the fiber used, is an absorption technique or utilizes absorption and adsorption properties simultaneously. Sorbent trapping is a three-step process (extraction of the analytes to the solid sorbent, desorption, and cold focusing), whereas SPME is more simple in use (sorption of analytes onto the fiber then desorption) [115]. The simplicity of SPME facilitates the development of normalised methods and standardisation [31]. SPME-GC-MS does not require an additional device connected to the gas chromatograph such as a cryotrap or a water removal device. On the other hand, as SPME methodology is limited by the commercially available fibres, its sensitivity is also limited. Sorbent traps may employ additional preconcentration, such as using higher volumes of the trapping material to enhance sensitivity [117]. The sensitivity of SPME is not as dependent on sample volume as sorbent traps; the limits of detection of the latter technique get better with a larger volume of sample [41]. SPME use is limited when large sample volumes are analysed. For example, the use of sorbent traps showed an order of magnitude lower limit of detection (LOD) than SPME for isoprene in human breath, when the same, $8 \mathrm{~L}$ breath samples were analysed [118]. LODs obtained in studies analysing VOCs as potential cancer biomarkers showed that PT extraction technique yielded better sensitivity (low ngl ${ }^{-1}$ in full scan mode) than SPME ( $\mu \mathrm{gl}^{-1}$ in full scan mode) $[80,119]$.

As selection of the appropriate fiber coating for analytes is a critical stage in the SPME methodology development, there are new fiber coatings under development with higher capacity and selectivity, which would enhance sensitivity such as molecularly imprinted polymers, multiwall carbon nanotubes, sol-gel technology, and polymeric ionic liquids (reviewed in $[120,121]$ ).

Other variations of SPME techniques such as stir bar sorptive extraction (SBSE), solid phase microextraction membrane, (or thin-film microextraction), and needle trap device have been successfully used for the collection of VOCs and so may be used in cancer studies in the future (reviewed in $[111,120])$. Needle trap device has been already used by Mochalski et al. [122] for analysis of VOCs in the HS of liver cancer cell line. Another microextraction method, single drop microextraction, was also introduced for the HS analysis of VOCs in cancerous blood. The technique is simple and rapid, uses trace amounts of solvents $(2 \mu \mathrm{L})$, and is less costly than SPME [106]. Barash et al. [73, 123] used Ultra II SKC passive (no purge) diffusion badges for the preconcentration of VOCs from the HS of the cell culture media. In this type of sampler sorbent traps serve as adsorption material, and extraction is based, as in SPME, on the equilibrium principles [124]. Offline sorbent trapping was also used by Amal et al. (with the use of TD) [71]. Finally, cryoconcentration was also used prior to analysis in a study, in order to investigate VOCs produced by leukaemia cell line. The VOCs were quantified in trace levels (low ppb). Separation of the analytes was achieved here by the use of multicolumn GC [125].

3.2. Detection Techniques. The main detection techniques that have been employed in VOC cancer biomarker studies are GC-MS, proton transfer reaction-mass spectrometry (PTR-MS), selected ion flow tube-mass spectrometry (SIFTMS), and gas sensors (electronic noses) (Table 3). Sampling and analytical techniques for the analysis of VOCs in biological samples are summarised in the recent review by Zhang et al. [111] and for breath analysis specifically in the reviews by Di Francesco et al. and Kim et al. [31, 40]. Advances and/or applications in gas sensor technology in breath analysis have been recently described in a number of reviews [126-132].

GC-MS is the most commonly used analytical technique for the investigation of potential VOC cancer biomarkers, due to its sensitivity and reliability in analyte identification. It gives the most detailed analytical information and identifies analytes with the most certainty, when compared to PTR-MS. The identification of VOCs with the use of PTR-MS can be tentative only as it is not possible to discriminate between compounds with the same molecular weight $[74,88,133]$. On the other hand, PTR-MS is the most sensitive method of all, with the limit of detection for aromatic hydrocarbons in low-ppb levels [134], or even as low as a few ppt [135]. It has been demonstrated to be more sensitive than GC-MS measurement by a factor of $\sim 20$ [134]. GC-MS was shown to have sensitivity for VOC analysis at the ppb and low ppt levels but it needs a further preconcentration step [96, 117]. SIFT-MS allows for the measurement of trace gases at subppb levels [136], but it is also reliable in the identification of compounds [134]. The advantage of PTR-MS and SIFT-MS over GC-MS is that they do not require a preconcentration step and can work in online (real time) mode. Therefore they are better techniques for the quantification of VOCs, as they provide instant quantification of all the analytes in the sample $[133,136]$ (Table 3). In comparison, SPMEGC-MS measures analytes semiquantitatively, as it involves competitive absorption of the compounds on the fiber [115]. GC-MS instruments are also more expensive. Nevertheless, instruments for all the techniques are not easy to use in clinical settings in terms of portability or transport [133]. Although the easily transportable SIFT (TransSIFT) and PTR (PTR-QMS 300) instruments have been introduced commercially $[136,137]$, their small sizes compromise their sensitivity. 
TABLE 3: Main characteristics of analytical techniques used in the studies of VOCs as potential cancer biomarkers. GC-MS: gas chromatography-mass spectrometry; IMS: ion mobility spectrometry; MCC: multicapillary column; PTR-MS: proton transfer reaction-mass spectrometry; SIFT-MS: selected ion flow tube-mass spectrometry.

\begin{tabular}{lcccc}
\hline Analytical technique & Sensitivity & Quantification & Mode & Compound identification \\
\hline GC-MS & Sub-ppb-low ppt ${ }^{1}[96,117]$ & Semiquantitative & Offline & Reliable \\
PTR-MS & Low ppb-low ppt $[134,135]$ & Absolute & Real-time & Tentative \\
SIFT-MS & Sub-ppb-low ppb [136] & Absolute & Real-time & Reliable \\
MCC-IMS & ppb-ppt [140] & Absolute & Real-time & Tentative \\
e-noses & Low ppb [150] & Semiquantitative & Real-time & - \\
\hline
\end{tabular}

${ }^{1}$ With preconcentration.

Another detection technique, ion mobility spectrometry (IMS), is not very common yet in the studies of VOCs as potential cancer biomarkers, but already has shown promising results. The first study which applied IMS for the analysis of VOCs in the exhaled breath of lung cancer patients and healthy subjects was performed by Westhoff et al. [138]. Discriminant analysis employing 23 VOC peaks identified individuals with or without a tumour with $100 \%$ accuracy. In another study, the detection of different VOC concentrations in the breath of cancer patients using IMS allowed for discrimination between different histological subtypes of lung cancer [139]. The IMS detector is characterised by low selectivity. Therefore, complex mixtures are analysed with the use of a preseparation technique such as multicapillary column (MCC) or GC $[140,141]$. Mainly IMS coupled with MCC has been used for breath analysis in the studies performed to date $[138-140,142]$. The advantages of MCC-IMS include very fast analysis ( $500 \mathrm{~s}$ for the breath sample), no need for preconcentration, and online analysis. In contrast to other analytical techniques, the use of MCC-IMS allows for the detection of all the analytes in a breath sample through their separation by retention time, mobility, and concentration and by creating a $3 \mathrm{D}$ visualisation of each compound in the chromatogram [138]. Although it does not allow for the identification of the analytes, IMS is a comparatively cheap detection technique with a potential for miniaturisation and is therefore one of the most promising, next to electronic noses, candidates to be used in a clinical setting [140].

Compared to mass spectrometric methods, the use of electronic noses does not require skilled personnel and is less time consuming [143]. These features, as well as the potential miniaturisation of such devices [144], make them ideal potential diagnostic tools to be used by general practitioners or even as devices for personal use. There have been several types of electronic noses used in the studies of VOCs in cancer [33, 73, 143, 145-147]. They are designed to recognise VOC patterns emitted from the analysed samples, but not to identify these VOCs [145]. Generally, electronic noses have not been designed to quantify analyte intensity [148]. However, construction of calibration curves allows for the semiquantitative detection of VOCs [149]. Quantification of VOCs with the use of an electronic nose has not been performed in any studies of cancer.

In terms of breath testing, such sensor systems could be cheap, rapid, and simple to use when they have been tailored for a specific use [31]. However, electronic noses are highly sensitive to moisture and relatively less sensitive (1-5 ppb) [150] and their effectiveness needs more validation studies as they have shown poor linearity and reproducibility [151]. Nevertheless, electronic noses constitute a very promising research area in the analysis of VOCs as potential cancer biomarkers. For example, a novel combination of a GC separation system and metal oxide sensor device has already shown very good accuracy in diagnosing bladder cancer [147]. Quartz microbalance gas sensors also demonstrated very good accuracy in differentiation between lung cancer patients and healthy controls [152]. Finally nanomaterialbased chemiresistors have shown the ability to distinguish not only between the breath of patients suffering from different cancer types [143], but also between early and advanced stages of lung cancer, between the types of lung cancer, and between malignant and benign pulmonary nodules [153].

\section{Conclusions and Future Directions}

Researchers take different approaches when looking for the potential biomarkers of cancer. The discussion starts with the issue of whether to choose an in vivo or in vitro system for study. Obviously the aim is to apply differential VOCs of cancer to a device that will enable the detection of cancer in the patient with $100 \%$ certainty, ideally noninvasively, as the less invasive a procedure is, the cheaper and more simple it will be to conduct. Whether it is going to be breath, blood, urine, or any other sample coming from the patient, at this stage, none of these matrices is ideal for looking for potential volatile biomarkers. The main reason is the uncertain origin of the detected VOCs, as their patterns may depend not only on the presence of the disease, but also on the long list of other variables such as genetic and environmental factors, age, gender, and so forth.

Therefore, it seems obvious to complement these studies with an investigation of the VOC profiles produced by tumours at the microcellular level, where an explanation of the presence of a compound in the chromatogram is more straightforward. The studies on cells are of great informative value about the biochemistry of tumours. However, with the in vitro approach, there are also some uncertainties arising. The main one is that there is little known about the complexity of VOCs metabolic pathways, between the VOC being produced by the tumour cells and its presence (or absence) in the sample from the patient. Nevertheless, 
in vitro studies are valuable tools in advancing the aim of cancer diagnosis.

Ideally, research should be directed to comparing VOC patterns in the HS of cancer cells or tissues of one particular patient with the compounds detected in breath, urine, and/or blood of the same patient. Also the selection of controls is crucial, in order to eliminate as many variables as possible. Without doubt, more studies are needed for the comparison of VOCs produced by tumour cells to the ones found in breath or biofluids, as well as for comparison of VOC patterns generated by many cell lines and primary tumour samples in order to profile as many cells as possible, so that an attempt can be made to find the common VOCs for particular types of cancer.

Each of the five types of analytical techniques that found application in the studies of VOCs has its advantages and disadvantages. Although it is more likely that a future tool to be used in the clinic will be an electronic sensor device, due to its cheaper cost, however, gas sensors still have poor sensitivities. Therefore other analytical techniques may be researched further. Consequently, for research purposes, it seems to be ideal to use the methods in complement.

Studies of the "scent of cancer" are really elegant in the simplicity of the idea; however there are still limitations of applying this idea clinically regardless of the technique used. At the moment certainty that any VOC is a biomarker of cancer is far from straightforward. Analysis of breath and other matrices investigating potential biomarkers of cancer is still in its infancy. Evidently large-scale screening studies are first required in order to describe normal profiles of VOCs in all matrices being studied. Knowledge about VOC concentration ranges for a normal, nondiseased state and validation studies using larger populations in relation to all forms of cancer will further evaluate the promising results of the existing studies of these diseases. And here surely the path to the use of VOCs as "smellprints" of cancer in the clinic lies in using information gleaned from a variety of different approaches in complement.

\section{Conflict of Interests}

The authors declare that there is no conflict of interests regarding the publication of this paper.

\section{References}

[1] WHO, World Cancer Report 2008, edited by P. Boyle and B. Levin, IARC Press, Lyon, France, 2008.

[2] R. K. Portenoy, H. T. Thaler, A. B. Kornblith et al., "Symptom prevalence, characteristics and distress in a cancer population," Quality of Life Research, vol. 3, no. 3, pp. 183-189, 1994.

[3] G. Young, J. A. Toretsky, A. B. Campbell, and A. E. Eskenazi, "Recognition of common childhood malignancies," American Family Physician, vol. 61, no. 7, pp. 2144-2154, 2000.

[4] J. A. de Barros, G. Valladares, A. R. Faria et al., "Early diagnosis of lung cancer: the great challenge. Epidemiological variables, clinical variables, staging and treatment," Jornal Brasileiro de Pneumologia, vol. 32, no. 3, pp. 221-227, 2006.
[5] A. K. Gupta, D. E. Brenner, and D. K. Turgeon, "Early detection of colon cancer: new tests on the horizon," Molecular Diagnosis \& Therapy, vol. 12, no. 2, pp. 77-85, 2008.

[6] NLSTRT (The National Lung Screening Trial Research Team), "Reduced lung-cancer mortality with low-dose computed tomographic screening," The New England Journal of Medicine, vol. 365, no. 5, pp. 395-409, 2011.

[7] J. D. Brooks, "Translational genomics: the challenge of developing cancer biomarkers," Genome Research, vol. 22, no. 2, pp. 183-187, 2012.

[8] R. D. Beger, "A review of applications of metabolomics in cancer," Metabolites, vol. 3, no. 3, pp. 552-574, 2013.

[9] A. Khadir and A. Tiss, "Proteomics approaches towards early detection and diagnosis of cancer," Journal of Carcinogenesis \& Mutagenesis, supplement 14, article 002, 16 pages, 2013.

[10] WHO, Indoor Air Quality: Organic Pollutants. Report on a WHO Meeting, Berlin (West) 23-27 August 1987, World Health Organization Regional Office for Europe, Copenhagen, Denmark, 1989.

[11] L. Pauling, A. B. Robinson, R. Teranishi, and P. Cary, "Quantitative analysis of urine vapor and breath by gas-liquid partition chromatography," Proceedings of the National Academy of Sciences of the United States of America, vol. 68, no. 10, pp. 23742376, 1971.

[12] C. Deng and X. Zhang, "A simple, rapid and sensitive method for determination of aldehydes in human blood by gas chromatography/mass spectrometry and solid-phase microextraction with on-fiber derivatization," Rapid Communications in Mass Spectrometry, vol. 18, no. 15, pp. 1715-1720, 2004.

[13] I. Ahmed, R. Greenwood, B. de Lacy Costello, N. M. Ratcliffe, and C. S. Probert, "An investigation of fecal volatile organic metabolites in irritable bowel syndrome," PLOS ONE, vol. 8, no. 3, Article ID e58204, 2013.

[14] M. Gallagher, C. J. Wysocki, J. J. Leyden, A. I. Spielman, X. Sun, and G. Preti, "Analyses of volatile organic compounds from human skin," British Journal of Dermatology, vol. 159, no. 4, pp. 780-791, 2008.

[15] W. Filipiak, A. Sponring, T. Mikoviny et al., "Release of volatile organic compounds (VOCs) from the lung cancer cell line CALU-1 in vitro," Cancer Cell International, vol. 8, article 17, 2008.

[16] H. J. O’Neill, S. M. Gordon, M. H. O’Neill, R. D. Gibbons, and J. P. Szidon, "A computerized classification technique for screening for the presence of breath biomarkers in lung cancer," Clinical Chemistry, vol. 34, no. 8, pp. 1613-1618, 1988.

[17] B. Ibrahim, M. Basanta, P. Cadden et al., "Non-invasive phenotyping using exhaled volatile organic compounds in asthma," Thorax, vol. 66, no. 9, pp. 804-809, 2011.

[18] M. Barker, M. Hengst, J. Schmid et al., "Volatile organic compounds in the exhaled breath of young patients with cystic fibrosis," European Respiratory Journal, vol. 27, no. 5, pp. 929936, 2006.

[19] M. Phillips, R. N. Cataneo, T. Cheema, and J. Greenberg, "Increased breath biomarkers of oxidative stress in diabetes mellitus," Clinica Chimica Acta, vol. 344, no. 1-2, pp. 189-194, 2004.

[20] M. Phillips, R. N. Cataneo, R. Condos et al., "Volatile biomarkers of pulmonary tuberculosis in the breath," Tuberculosis, vol. 87, no. 1, pp. 44-52, 2007.

[21] C. O. Phillips, Y. Syed, N. M. Parthaláin, R. Zwiggelaar, T. C. Claypole, and K. E. Lewis, "Machine learning methods on 
exhaled volatile organic compounds for distinguishing COPD patients from healthy controls," Journal of Breath Research, vol. 6, no. 3, Article ID 036003, 2012.

[22] M. Phillips, J. P. Boehmer, R. N. Cataneo et al., "Heart allograft rejection: detection with breath alkanes in low levels (the HARDBALL study)," Journal of Heart and Lung Transplantation, vol. 23, no. 6, pp. 701-708, 2004.

[23] W. Cao and Y. Duan, "Breath analysis: potential for clinical diagnosis and exposure assessment," Clinical Chemistry, vol. 52, no. 5, pp. 800-811, 2006.

[24] J. E. Szulejko, M. McCulloch, J. Jackson, D. L. McKee, J. C. Walker, and T. Solouki, "Evidence for cancer biomarkers in exhaled breath," IEEE Sensors Journal, vol. 10, no. 1, pp. 185-210, 2010.

[25] P. Mochalski, J. King, M. Haas, K. Unterkofler, A. Amann, and G. Mayer, "Blood and breath profiles of volatile organic compounds in patients with end-stage renal disease," BMC Nephrology, vol. 15, no. 43, pp. 1-14, 2014.

[26] C. Deng, X. Zhang, and N. Li, "Investigation of volatile biomarkers in lung cancer blood using solid-phase microextraction and capillary gas chromatography-mass spectrometry," Journal of Chromatography B, vol. 808, no. 2, pp. 269-277, 2004.

[27] M. Hakim, Y. Y. Broza, O. Barash et al., "Volatile organic compounds of lung cancer and possible biochemical pathways," Chemical Reviews, vol. 112, no. 11, pp. 5949-5966, 2012.

[28] B. Buszewski, A. Ulanowska, T. Kowalkowski, and K. Cieliski, "Investigation of lung cancer biomarkers by hyphenated separation techniques and chemometrics," Clinical Chemistry and Laboratory Medicine, vol. 50, no. 3, pp. 573-581, 2012.

[29] M. Phillips, J. Herrera, S. Krishnan, M. Zain, J. Greenberg, and R. N. Cataneo, "Variation in volatile organic compounds in the breath of normal humans," Journal of Chromatography B: Biomedical Sciences and Applications, vol. 729, no. 1-2, pp. 7588, 1999.

[30] J. Kwak and G. Preti, "Volatile disease biomarkers in breath: a critique," Current Pharmaceutical Biotechnology, vol. 12, no. 7, pp. 1067-1074, 2011.

[31] F. Di Francesco, R. Fuoco, M. G. Trivella, and A. Ceccarini, "Breath analysis: trends in techniques and clinical applications," Microchemical Journal, vol. 79, no. 1-2, pp. 405-410, 2005.

[32] S. Kischkel, W. Miekisch, A. Sawacki et al., "Breath biomarkers for lung cancer detection and assessment of smoking related effects-confounding variables, influence of normalization and statistical algorithms," Clinica Chimica Acta, vol. 411, no. 21-22, pp. 1637-1644, 2010.

[33] C. di Natale, A. Macagnano, E. Martinelli et al., "Lung cancer identification by the analysis of breath by means of an array of non-selective gas sensors," Biosensors and Bioelectronics, vol. 18, no. 10, pp. 1209-1218, 2003.

[34] R. F. Machado, "Identifying chronic obstructive pulmonary disease and asthma by exhaled breath analysis: does the (e)Nose know?" American Journal of Respiratory and Critical Care Medicine, vol. 180, no. 11, pp. 1038-1039, 2009.

[35] M. Phillips, "Method for the collection and assay of volatile organic compounds in breath," Analytical Biochemistry, vol. 247, no. 2, pp. 272-278, 1997.

[36] J. D. Pleil, M. A. Stiegel, and T. H. Risby, "Clinical breath analysis: discriminating between human endogenous compounds and exogenous (environmental) chemical confounders," Journal of Breath Research, vol. 7, no. 1, Article ID 017107, 2013.

[37] A. Manolis, "The diagnostic potential of breath analysis," Clinical Chemistry, vol. 29, no. 1, pp. 5-15, 1983.
[38] P. Montuschi, "Analysis of exhaled breath condensate in respiratory medicine: methodological aspects and potential clinical applications," Therapeutic Advances in Respiratory Disease, vol. 1, no. 1, pp. 5-23, 2007.

[39] W. Miekisch, S. Kischkel, A. Sawacki, T. Liebau, M. Mieth, and J. K. Schubert, "Impact of sampling procedures on the results of breath analysis," Journal of Breath Research, vol. 2, no. 2, Article ID 026007, 2008.

[40] K.-H. Kim, S. A. Jahan, and E. Kabir, "A review of breath analysis for diagnosis of human health," TrAC: Trends in Analytical Chemistry, vol. 33, pp. 1-8, 2012.

[41] M. Alonso and J. M. Sanchez, "Analytical challenges in breath analysis and its application to exposure monitoring," TrACTrends in Analytical Chemistry, vol. 44, pp. 78-89, 2013.

[42] J. Beauchamp, "Inhaled today, not gone tomorrow: pharmacokinetics and environmental exposure of volatiles in exhaled breath," Journal of Breath Research, vol. 5, no. 3, Article ID 037103, 2011.

[43] P. Poulin and K. Krishnan, "A mechanistic algorithm for predicting blood: air partition coefficients of organic chemicals with the consideration of reversible binding in hemoglobin," Toxicology and Applied Pharmacology, vol. 136, no. 1, pp. 131-137, 1996.

[44] C. L. Silva, M. Passos, and J. S. Câmara, "Investigation of urinary volatile organic metabolites as potential cancer biomarkers by solid-phase microextraction in combination with gas chromatography-mass spectrometry," British Journal of Cancer, vol. 105, no. 12, pp. 1894-1904, 2011.

[45] I. Horváth, Z. Lázár, N. Gyulai, M. Kollai, and G. Losonczy, "Exhaled biomarkers in lung cancer," European Respiratory Journal, vol. 34, no. 1, pp. 261-275, 2009.

[46] M. Phillips, K. Gleeson, J. M. B. Hughes et al., "Volatile organic compounds in breath as markers of lung cancer: a crosssectional study," The Lancet, vol. 353, no. 9168, pp. 1930-1933, 1999.

[47] A. A. Aksenov, A. Gojova, W. Zhao et al., "Characterization of volatile organic compounds in human leukocyte antigen heterologous expression systems: a cell's 'chemical door fingerprint", ChemBioChem, vol. 13, no. 7, pp. 1053-1059, 2012.

[48] M. Bunge, N. Araghipour, T. Mikoviny et al., "On-line monitoring of microbial volatile metabolites by proton transfer reaction-mass spectrometry," Applied and Environmental Microbiology, vol. 74, no. 7, pp. 2179-2186, 2008.

[49] C. E. Garner, S. Smith, B. D. L. Costello et al., "Volatile organic compounds from feces and their potential for diagnosis of gastrointestinal disease," The FASEB Journal, vol. 21, no. 8, pp. 1675-1688, 2007.

[50] J. Zhu, H. D. Bean, Y.-M. Kuo, and J. E. Hill, "Fast detection of volatile organic compounds from bacterial cultures by secondary electrospray ionization-mass spectrometry," Journal of Clinical Microbiology, vol. 48, no. 12, pp. 4426-4431, 2010.

[51] M. Syhre, L. Manning, S. Phuanukoonnon, P. Harino, and S. T. Chambers, "The scent of Mycobacterium tuberculosis-part II breath," Tuberculosis, vol. 89, no. 4, pp. 263-266, 2009.

[52] J.-N. Cornu, G. Cancel-Tassin, V. Ondet, C. Girardet, and O. Cussenot, "Olfactory detection of prostate cancer by dogs sniffing urine: a step forward in early diagnosis," European Urology, vol. 59, no. 2, pp. 197-201, 2011.

[53] G. Horvath, G. A. K. Järverud, S. Järverud, and I. Horváth, "Human ovarian carcinomas detected by specific odor," Integrative Cancer Therapies, vol. 7, no. 2, pp. 76-80, 2008. 
[54] G. Horvath, H. Andersson, and G. Paulsson, "Characteristic odour in the blood reveals ovarian carcinoma," BMC Cancer, vol. 10 , article $643,2010$.

[55] M. McCulloch, T. Jezierski, M. Broffman, A. Hubbard, K. Turner, and T. Janecki, "Diagnostic accuracy of canine scent detection in early- and late-stage lung and breast cancers," Integrative Cancer Therapies, vol. 5, no. 1, pp. 30-39, 2006.

[56] D. P. Pickel, G. P. Manucy, D. B. Walker, S. B. Hall, and J. C. Walker, "Evidence for canine olfactory detection of melanoma," Applied Animal Behaviour Science, vol. 89, no. 1-2, pp. 107-116, 2004.

[57] C. M. Willis, S. M. Church, C. M. Guest et al., "Olfactory detection of human bladder cancer by dogs: proof of principle study," British Medical Journal, vol. 329, no. 7468, pp. 712-714, 2004.

[58] K. Matsumura, M. Opiekun, H. Oka et al., "Urinary volatile compounds as biomarkers for lung cancer: a proof of principle study using odor signatures in mouse models of lung cancer," PLoS ONE, vol. 5, no. 1, Article ID e8819, 2010.

[59] C. Deng, X. Zhang, and N. Li, "Development of headspace solid-phase microextraction with on-fiber derivatization for determination of hexanal and heptanal in human blood," Journal of Chromatography B: Analytical Technologies in the Biomedical and Life Sciences, vol. 813, no. 1-2, pp. 47-52, 2004.

[60] M. Yazdanpanah, X. Luo, R. Lau, M. Greenberg, L. J. Fisher, and D. C. Lehotay, "Cytotoxic aldehydes as possible markers for childhood cancer," Free Radical Biology \& Medicine, vol. 23, no. 6, pp. 870-878, 1997.

[61] R. Xue, L. Dong, S. Zhang et al., "Investigation of volatile biomarkers in liver cancer blood using solid-phase microextraction and gas chromatography/mass spectrometry," Rapid Communications in Mass Spectrometry, vol. 22, no. 8, pp. 11811186, 2008.

[62] K. A. Kouremenos, M. Johansson, and P. J. Marriott, "Advances in gas chromatographic methods for the identification of biomarkers in cancer," Journal of Cancer, vol. 3, no. 1, pp. 404420, 2012.

[63] C. L. Silva, M. Passos, and J. S. Câmara, "Solid phase microextraction, mass spectrometry and metabolomic approaches for detection of potential urinary cancer biomarkers-a powerful strategy for breast cancer diagnosis," Talanta, vol. 89, pp. 360$368,2012$.

[64] J. Huang, S. Kumar, N. Abbassi-Ghadi, P. Španěl, D. Smith, and G. B. Hanna, "Selected ion flow tube mass spectrometry analysis of volatile metabolites in urine headspace for the profiling of gastro-esophageal cancer," Analytical Chemistry, vol. 85, no. 6, pp. 3409-3416, 2013.

[65] R. Guadagni, N. Miraglia, A. Simonelli et al., "Solid-phase microextraction-gas chromatography-mass spectrometry method validation for the determination of endogenous substances: urinary hexanal and heptanal as lung tumor biomarkers," Analytica Chimica Acta, vol. 701, no. 1, pp. 29-36, 2011.

[66] K. Jobu, C. Sun, S. Yoshioka et al., "Metabolomics study on the biochemical profiles of odor elements in urine of human with bladder cancer," Biological and Pharmaceutical Bulletin, vol. 35 , no. 4, pp. 639-642, 2012.

[67] G. A. Mills and V. Walker, "Headspace solid-phase microextraction procedures for gas chromatographic analysis of biological fluids and materials," Journal of Chromatography A, vol. 902, no. 1, pp. 267-287, 2000.
[68] Z. León, J. C. García-Cañaveras, M. T. Donato, and A. Lahoz, "Mammalian cell metabolomics: experimental design and sample preparation," Electrophoresis, vol. 34, no. 19, pp. 2762-2775, 2013.

[69] D. Zimmermann, M. Hartmann, M. P. Moyer, J. Nolte, and J. I. Baumbach, "Determination of volatile products of human colon cell line metabolism by GC/MS analysis," Metabolomics, vol. 3, no. 1, pp. 13-17, 2007.

[70] J. Kwak, M. Gallagher, M. H. Ozdener et al., "Volatile biomarkers from human melanoma cells," Journal of Chromatography B: Analytical Technologies in the Biomedical and Life Sciences, vol. 931, pp. 90-96, 2013.

[71] H. Amal, L. Ding, B.-B. Liu et al., "The scent fingerprint of hepatocarcinoma: in-vitro metastasis prediction with volatile organic compounds (VOCs)," International Journal of Nanomedicine, vol. 7, pp. 4135-4146, 2012.

[72] A. Sponring, W. Filipiak, T. Mikoviny et al., "Release of volatile organic compounds from the lung cancer cell line NCI-H2087 in vitro," Anticancer Research, vol. 29, no. 1, pp. 419-426, 2009.

[73] O. Barash, N. Peled, U. Tisch, P. A. Bunn, F. R. Hirsch, and H. Haick, "Classification of lung cancer histology by gold nanoparticle sensors," Nanomedicine: Nanotechnology, Biology, and Medicine, vol. 8, no. 5, pp. 580-589, 2012.

[74] C. Brunner, W. Szymczak, V. Höllriegl et al., "Discrimination of cancerous and non-cancerous cell lines by headspace-analysis with PTR-MS," Analytical and Bioanalytical Chemistry, vol. 397, no. 6, pp. 2315-2324, 2010.

[75] J. Sulé-Suso, A. Pysanenko, P. Španěl, and D. Smith, "Quantification of acetaldehyde and carbon dioxide in the headspace of malignant and non-malignant lung cells in vitro by SIFT-MS," Analyst, vol. 134, no. 12, pp. 2419-2425, 2009.

[76] J. Yu, D. Wang, L. Wang, P. Wang, Y. Hu, and K. Ying, "Detection of lung cancer with volatile organic biomarkers in exhaled breath and lung cancer cells," in Proceedings of the 13rd International Symposium on Olfaction and Electronic Nose, M. Prado and G. G. Sberveglieri, Eds., pp. 198-201, AIP Conference Proceedings, Brescia, Italy, April 2009.

[77] J. He, P. M.-L. Sinues, F. M. Hollmén, X. Li, M. Detmar, and R. Zenobi, "Fingerprinting breast cancer vs. normal mammary cells by mass spectrometric analysis of volatiles," Scientific Reports, vol. 4, no. 5196, pp. 1-6, 2014.

[78] J. Chen, W. Wang, S. Lv et al., "Metabonomics study of liver cancer based on ultra performance liquid chromatography coupled to mass spectrometry with HILIC and RPLC separations," Analytica Chimica Acta, vol. 650, no. 1, pp. 3-9, 2009.

[79] Y. Hanai, K. Shimono, H. Oka, Y. Baba, K. Yamazaki, and G. K. Beauchamp, "Analysis of volatile organic compounds released from human lung cancer cells and from the urine of tumorbearing mice," Cancer Cell International, vol. 12, article 7, 2012.

[80] W. Filipiak, A. Sponring, A. Filipiak et al., "TD-GC-MS analysis of volatile metabolites of human lung cancer and normal cells in vitro," Cancer Epidemiology Biomarkers and Prevention, vol. 19, no. 1, pp. 182-195, 2010.

[81] A. V. Rutter, T. W. E. Chippendale, Y. Yang, P. Španěl, D. Smith, and J. Sulé-Suso, "Quantification by SIFT-MS of acetaldehyde released by lung cells in a 3D model.," The Analyst, vol. 138, no. 1, pp. 91-95, 2013.

[82] D. Smith, T. Wang, J. Sulé-Suso, P. Španěl, and A. El Haj, "Quantification of acetaldehyde released by lung cancer cells in vitro using selected ion flow tube mass spectrometry," Rapid Communications in Mass Spectrometry, vol. 17, no. 8, pp. 845850, 2003. 
[83] P. Hughes, D. Marshall, Y. Reid, H. Parkes, and C. Gelber, “The costs of using unauthenticated, over-passaged cell lines: how much more data do we need?" BioTechniques, vol. 43, no. 5, pp. 575-586, 2007.

[84] C. A. Acevedo, E. Y. Sánchez, J. G. Reyes, and M. E. Young, "Volatile organic compounds produced by human skin cells," Biological Research, vol. 40, no. 3, pp. 347-355, 2007.

[85] C. A. Acevedo, E. Y. Sanchez, J. G. Reyes, and M. E. Young, "Volatile profiles of human skin cell cultures in different degrees of senescence," Journal of Chromatography B, vol. 878, no. 3-4, pp. 449-455, 2010.

[86] M. Hartmann, D. Zimmermann, and J. Nolte, "Changes of the metabolism of the colon cancer cell line SW-480 under serumfree and serum-reduced growth conditions," In Vitro Cellular \& Developmental Biology - Animal, vol. 44, no. 10, pp. 458-463, 2009.

[87] J. S. Pyo, H. K. Ju, J. H. Park, and S. W. Kwon, "Determination of volatile biomarkers for apoptosis and necrosis by solid-phase microextraction-gas chromatography/mass spectrometry: a pharmacometabolomic approach to cisplatin's cytotoxicity to human lung cancer cell lines," Journal of Chromatography B, vol. 876, no. 2, pp. 170-174, 2008.

[88] A. Bajtarevic, C. Ager, M. Pienz et al., "Noninvasive detection of lung cancer by analysis of exhaled breath," BMC Cancer, vol. 9, article 348, 2009.

[89] U. Kalluri, M. Naiker, and M. A. Myers, "Cell culture metabolomics in the diagnosis of lung cancer-the influence of cell culture conditions," Journal of Breath Research, vol. 8, no. 2, Article ID 027109, pp. 1-10, 2014.

[90] P. Vaupel, "Tumor microenvironmental physiology and its implications for radiation oncology," Seminars in Radiation Oncology, vol. 14, no. 3, pp. 198-206, 2004.

[91] W. Filipiak, A. Filipiak, A. Sponring et al., "Comparative analyses of volatile organic compounds (VOCs) from patients, tumors and transformed cell lines for the validation of lung cancer-derived breath markers," Journal of Breath Research, vol. 8, no. 2, Article ID 027111, 2014.

[92] D. Poli, M. Goldoni, A. Caglieri et al., "Breath analysis in non small cell lung cancer patients after surgical tumour resection," Acta Biomedica de l'Ateneo Parmense, vol. 79, no. 1, pp. 64-72, 2008.

[93] D. Poli, P. Carbognani, M. Corradi et al., "Exhaled volatile organic compounds in patients with non-small cell lung cancer: cross sectional and nested short-term follow-up study," Respiratory Research, vol. 6, article 71, 2005.

[94] M. Phillips, N. Altorki, J. H. M. Austin et al., "Prediction of lung cancer using volatile biomarkers in breath," Cancer Biomarkers, vol. 3, no. 2, pp. 95-109, 2007.

[95] M. Phillips, N. Altorki, J. H. M. Austin et al., "Detection of lung cancer using weighted digital analysis of breath biomarkers," Clinica Chimica Acta, vol. 393, no. 2, pp. 76-84, 2008.

[96] P. Fuchs, C. Loeseken, J. K. Schubert, and W. Miekisch, "Breath gas aldehydes as biomarkers of lung cancer," International Journal of Cancer, vol. 126, no. 11, pp. 2663-2670, 2010.

[97] E. M. Gaspar, A. F. Lucena, J. D. da Costa, and H. C. das Neves, "Organic metabolites in exhaled human breath-a multivariate approach for identification of biomarkers in lung disorders," Journal of Chromatography A, vol. 1216, no. 14, pp. 2749-2756, 2009.

[98] M. Phillips, R. N. Cataneo, A. R. C. Cummin et al., "Detection of lung cancer with volatile markers in the breath," Chest, vol. 123, no. 6, pp. 2115-2123, 2003.
[99] H. Yu, L. Xu, and P. Wang, "Solid phase microextraction for analysis of alkanes and aromatic hydrocarbons in human breath," Journal of Chromatography B: Analytical Technologies in the Biomedical and Life Sciences, vol. 826, no. 1-2, pp. 69-74, 2005.

[100] S. Toyokuni, "Molecular mechanisms of oxidative stressinduced carcinogenesis: from epidemiology to oxygenomics," IUBMB Life, vol. 60, no. 7, pp. 441-447, 2008.

[101] M. Eggink, M. Wijtmans, A. Kretschmer et al., "Targeted LCMS derivatization for aldehydes and carboxylic acids with a new derivatization agent 4-APEBA," Analytical and Bioanalytical Chemistry, vol. 397, no. 2, pp. 665-675, 2010.

[102] F. J. Romero, F. Bosch-Morell, M. J. Romero et al., "Lipid peroxidation products and antioxidants in human disease," Environmental Health Perspectives, vol.106, no. 5, pp. 1229-1234, 1998.

[103] C. M. Kneepkers, G. Lepage, and C. C. Roy, "The potential of the hydrocarbon breath test as a measure of lipid peroxidation," Free Radical Biology and Medicine, vol. 17, no. 2, pp. 127-160, 1994.

[104] T. Mitsui and T. Kondo, "Inadequacy of theoretical basis of breath methylated alkane contour for assessing oxidative stress," Clinica Chimica Acta, vol. 333, no. 1, p. 91, 2003.

[105] D. A. Cancilla and S. S. Que Hee, "O- $(2,3,4,5,6-$ pentafluorophenyl)methylhydroxylamine hydrochloride: a versatile reagent for the determination of carbonyl-containing compounds," Journal of Chromatography A, vol. 627, no. 1-2, pp. $1-16,1992$.

[106] N. Li, C. Deng, X. Yin, N. Yao, X. Shen, and X. Zhang, "Gas chromatography-mass spectrometric analysis of hexanal and heptanal in human blood by headspace single-drop microextraction with droplet derivatization," Analytical Biochemistry, vol. 342, no. 2, pp. 318-326, 2005.

[107] L. Lili, H. Xu, D. Song, Y. Cui, S. Hu, and G. Zhang, "Analysis of volatile aldehyde biomarkers in human blood by derivatization and dispersive liquid-liquid microextraction based on solidification of floating organic droplet method by high performance liquid chromatography," Journal of Chromatography A, vol. 1217, no. 16, pp. 2365-2370, 2010.

[108] D. Poli, M. Goldoni, M. Corradi et al., "Determination of aldehydes in exhaled breath of patients with lung cancer by means of on-fiber-derivatisation SPME-GC/MS," Journal of Chromatography B: Analytical Technologies in the Biomedical and Life Sciences, vol. 878, no. 27, pp. 2643-2651, 2010.

[109] H. Kataoka and K. Saito, "Recent advances in SPME techniques in biomedical analysis," Journal of Pharmaceutical and Biomedical Analysis, vol. 54, no. 5, pp. 926-950, 2011.

[110] H. Kataoka, "Current developments and future trends in solid-phase microextraction techniques for pharmaceutical and biomedical analyses," Analytical Sciences, vol. 27, no. 9, pp. 893905, 2011.

[111] Z. Zhang, Y. Ma, and G. Li, "Progress on the analytical methodology for biological volatile organic compounds," Analytical Methods, vol. 5, no. 1, pp. 20-29, 2013.

[112] B. Bojko and J. Pawliszyn, "The benefits of using solid-phase microextraction as a greener sample preparation technique," Bioanalysis, vol. 4, no. 11, pp. 1263-1265, 2012.

[113] K. K. Kleeberg, N. Dobberstein, N. Hinrichsen, A. Muller, P. Weber, and H. Steinhart, "Sampling procedures with special focus on automatization," in Advances in Food Diagnostics, L. M. L. Nollet and F. Toldar, Eds., pp. 253-294, Blackwell, Oxford, UK, 2007. 
[114] B. Kolb, "Headspace sampling with capillary columns," Journal of Chromatography A, vol. 842, no. 1-2, pp. 163-205, 1999.

[115] J. Pawliszyn, “Theory of solid-phase microextraction," Journal of Chromatographic Science, vol. 38, no. 7, pp. 270-278, 2000.

[116] R. E. Shirey, "SPME commercial devices and fibre coatings", in Handbook of Solid Phase Microextraction, J. Pawliszyn, Ed., pp. 87-115, Chemical Industry Press, Waterloo, Canada, 2009.

[117] T. Ligor, M. Ligor, A. Amann et al., "The analysis of healthy volunteers' exhaled breath by the use of solid-phase microextraction and GC-MS," Journal of Breath Research, vol. 2, no. 4, Article ID 046006, pp. 1-8, 2008.

[118] R. Hyšpler, Š. Crhová, J. Gasparič, Z. Zadák, M. Čížková, and V. Balasová, "Determination of isoprene in human expired breath using solid-phase microextraction and gas chromatographymass spectrometry," Journal of Chromatography B: Biomedical Sciences and Applications, vol. 739, no. 1, pp. 183-190, 2000.

[119] T. Ligor, J. Szeliga, M. Jackowski, and B. Buszewski, "Preliminary study of volatile organic compounds from breath and stomach tissue by means of solid phase microextraction and gas chromatography-mass spectrometry," Journal of Breath Research, vol. 1, no. 1, Article ID 016001, 2007.

[120] C. Duan, Z. Shen, D. Wu, and Y. Guan, "Recent developments in solid-phase microextraction for on-site sampling and sample preparation," TrAC-Trends in Analytical Chemistry, vol. 30, no. 10, pp. 1568-1574, 2011.

[121] E. A. S. Silva, S. Risticevic, and J. Pawliszyn, "Recent trends in SPME concerning sorbent materials, configurations and in vivo applications," TrAC Trends in Analytical Chemistry, vol. 43, pp. 24-36, 2013.

[122] P. Mochalski, A. Sponring, J. King, K. Unterkofler, J. Troppmair, and A. Amann, "Release and uptake of volatile organic compounds by human hepatocellular carcinoma cells (HepG2) in vitro," Cancer Cell International, vol. 13, no. 1, article 72, 2013.

[123] O. Barash, N. Peled, F. R. Hirsch, and H. Haick, "Sniffing the unique 'Odor Print' of non-small-cell lung cancer with gold nanoparticles," Small, vol. 5, no. 22, pp. 2618-2624, 2009.

[124] B. Vrana, G. A. Mills, I. J. Allan et al., "Passive sampling techniques for monitoring pollutants in water," Trends in Analytical Chemistry, vol. 24, no. 10, pp. 845-868, 2005.

[125] H. W. Shin, B. J. Umber, S. Meinardi et al., "Acetaldehyde and hexanaldehyde from cultured white cells," Journal of Translational Medicine, vol. 7, article 31, 2009.

[126] Y. Adiguzel and H. Kulah, "Breath sensors for lung cancer diagnosis," Biosensors and Bioelectronics, vol. 65, pp. 121-138, 2015.

[127] G. Konvalina and H. Haick, "Sensors for breath testing: from nanomaterials to comprehensive disease detection," Accounts of Chemical Research, vol. 47, no. 1, pp. 66-76, 2014.

[128] W. Li, H. Y. Liu, Z. R. Jia et al., "Advances in the early detection of lung cancer using analysis of volatile organic compounds from imaging to sensors," Asian Pacific Journal of Cancer Prevention, vol. 15, no. 11, pp. 4377-4384, 2014.

[129] M. Righettoni, A. Amann, and S. E. Pratsinis, "Breath analysis by nanostructured metal oxides as chemo-resistive gas sensors," Materials Today, vol. 18, no. 3, pp. 163-171, 2015.

[130] M. K. Nakhleh, Y. Y. Broza, and H. Haick, "Monolayercapped gold nanoparticles for disease detection from breath," Nanomedicine, vol. 9, no. 13, pp. 1991-2002, 2014.

[131] C. Di Natale, R. Paolesse, E. Martinelli, and R. Capuano, "Solid-state gas sensors for breath analysis: a review," Analytica Chimica Acta, vol. 824, pp. 1-17, 2014.
[132] Y. Y. Broza and H. Haick, "Nanomaterial-based sensors for detection of disease by volatile organic compounds," Nanomedicine, vol. 8, no. 5, pp. 785-806, 2013.

[133] A. Wehinger, A. Schmid, S. Mechtcheriakov et al., "Lung cancer detection by proton transfer reaction mass-spectrometric analysis of human breath gas," International Journal of Mass Spectrometry, vol. 265, no. 1, pp. 49-59, 2007.

[134] I. Kushch, K. Schwarz, L. Schwentner et al., "Compounds enhanced in a mass spectrometric profile of smokers' exhaled breath versus non-smokers as determined in a pilot study using PTR-MS," Journal of Breath Research, vol. 2, no. 2, Article ID 026002, 2008.

[135] W. Lindinger, A. Hansel, and A. Jordan, "On-line monitoring of volatile organic compounds at pptv levels by means of proton-transfer-reaction mass spectrometry (PTR-MS). Medical applications, food control and environmental research," International Journal of Mass Spectrometry and Ion Processes, vol. 173, no. 3, pp. 191-241, 1998.

[136] D. Smith and P. Španěl, "Selected ion flow tube mass spectrometry (SIFT-MS) for on-line trace gas analysis," Mass Spectrometry Reviews, vol. 24, no. 5, pp. 661-700, 2005.

[137] Ionicon Analytik, "PTR-QMS 300" on the IONICON Analytik Website, 2013, http://www.ionicon.com/products/ptr-ms/ ptrqms/cptrms.html.

[138] M. Westhoff, P. Litterst, L. Freitag, W. Urfer, S. Bader, and J.I. Baumbach, "Ion mobility spectrometry for the detection of volatile organic compounds in exhaled breath of patients with lung cancer: results of a pilot study," Thorax, vol. 64, no. 9, pp. 744-748, 2009.

[139] K. Darwiche, J. I. Baumbach, U. Sommerwerck, H. Teschler, and L. Freitag, "Bronchoscopically obtained volatile biomarkers in lung cancer," Lung, vol. 189, no. 6, pp. 445-452, 2011.

[140] A. Ulanowska, M. Ligor, A. Amann, and B. Buszewski, "Determination of volatile organic compounds in exhaled breath by ion mobility spectrometry," Chemia Analityczna, vol. 53, no. 6, pp. 953-965, 2008.

[141] H. Lord, Y. Yu, A. Segal, and J. Pawliszyn, "Breath analysis and monitoring by membrane extraction with sorbent interface," Analytical Chemistry, vol. 74, no. 21, pp. 5650-5657, 2002.

[142] H. Handa, A. Usuba, S. Maddula, J. I. Baumbach, M. Mineshita, and T. Miyazawa, "Exhaled breath analysis for lung cancer detection using ion mobility spectrometry," PLoS ONE, vol. 9, no. 12, Article ID e114555, 2014.

[143] G. Peng, M. Hakim, Y. Y. Broza et al., "Detection of lung, breast, colorectal, and prostate cancers from exhaled breath using a single array of nanosensors," British Journal of Cancer, vol. 103, no. 4, pp. 542-551, 2010.

[144] C. Hagleitner, A. Hierlemann, D. Lange et al., "Smart singlechip gas sensor microsystem," Nature, vol. 414, no. 6861, pp. 293-296, 2001.

[145] S. Dragonieri, J. T. Annema, R. Schot et al., "An electronic nose in the discrimination of patients with non-small cell lung cancer and COPD," Lung Cancer, vol. 64, no. 2, pp. 166-170, 2009.

[146] P. J. Mazzone, J. Hammel, R. Dweik et al., "Diagnosis of lung cancer by the analysis of exhaled breath with a colorimetric sensor array," Thorax, vol. 62, no. 7, pp. 565-568, 2007.

[147] T. Khalid, P. White, B. D. L. Costello et al., "A pilot study combining a GC-sensor device with a statistical model for the identification of bladder cancer from urine headspace," PLoS ONE, vol. 8, no. 7, Article ID e69602, 2013. 
[148] F. Röck, N. Barsan, and U. Weimar, "Electronic nose: current status and future trends," Chemical Reviews, vol. 108, no. 2, pp. 705-725, 2008.

[149] D. Gao, J. Ji, J. Gong, and C. Cai, "Quantitative analysis of different volatile organic compounds using an improved electronic nose," Measurement Science and Technology, vol. 23, no. 10, Article ID 105103, 2012.

[150] E. H. Oh, H. S. Song, and T. H. Park, "Recent advances in electronic and bioelectronic noses and their biomedical applications," Enzyme and Microbial Technology, vol. 48, no. 6-7, pp. 427-437, 2011.

[151] F. Biasioli, C. Yeretzian, T. D. Märk, J. Dewulf, and H. van Langenhove, "Direct-injection mass spectrometry adds the time dimension to (B)VOC analysis," Trends in Analytical Chemistry, vol. 30, no. 7, pp. 1003-1017, 2011.

[152] C. Di Natale, A. Macagnano, E. Martinelli et al., "Lung cancer identification by the analysis of breath by means of an array of non-selective gas sensors," Biosensors and Bioelectronics, vol. 18, no. 10, pp. 1209-1218, 2003.

[153] N. Peled, M. Hakim, P. A. Bunn et al., "Non-invasive breath analysis of pulmonary nodules," Journal of Thoracic Oncology, vol. 7, no. 10, pp. 1528-1533, 2012.

[154] A. Bartolazzi, M. Santonico, G. Pennazza et al., "A sensor array and GC study about VOCs and cancer cells," Sensors and Actuators, B: Chemical, vol. 146, no. 2, pp. 483-488, 2010.

[155] S. Kato, P. J. Burke, D. J. Fenick, D. J. Taatjes, V. M. Bierbaum, and T. H. Koch, "Mass spectrometric measurement of formaldehyde generated in breast cancer cells upon treatment with anthracycline antitumor drugs," Chemical Research in Toxicology, vol. 13, no. 6, pp. 509-516, 2000.

[156] S. Kato, P. J. Burke, T. H. Koch, and V. M. Bierbaum, "Formalehyde in human cancer cells: detection by preconcentrationchemical ionization mass spectrometry," Analytical Chemistry, vol. 73, no. 13, pp. 2992-2997, 2001.

[157] S. Kato, G. C. Post, V. M. Bierbaum, and T. H. Koch, "Chemical ionization mass spectrometric determination of acrolein in human breast cancer cells," Analytical Biochemistry, vol. 305, no. 2, pp. 251-259, 2002. 


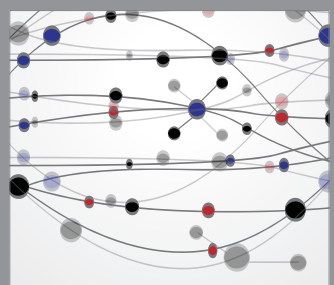

The Scientific World Journal
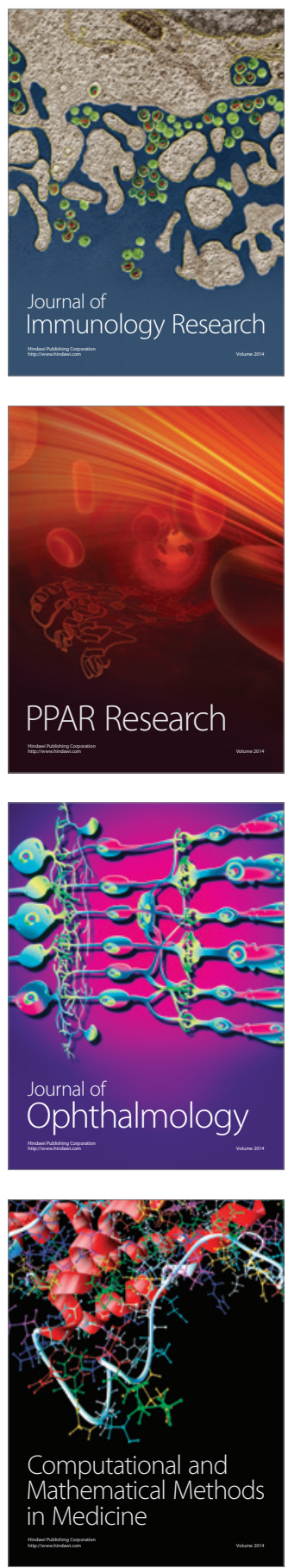

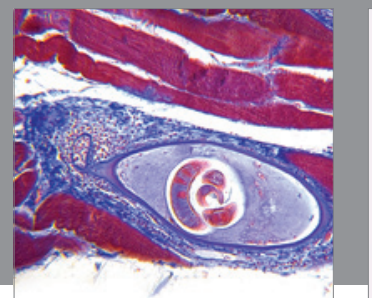

Gastroenterology

Research and Practice
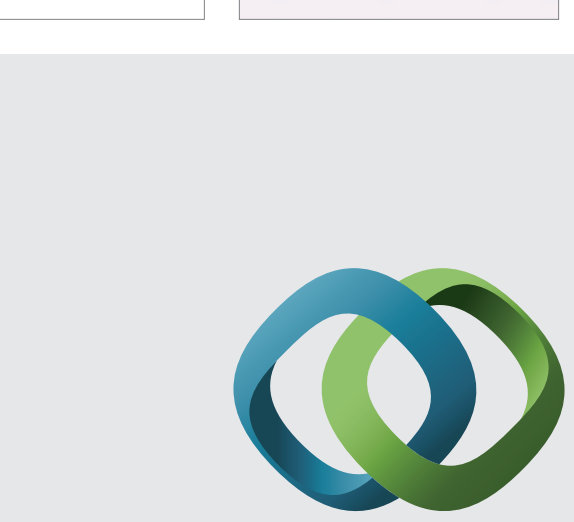

\section{Hindawi}

Submit your manuscripts at

http://www.hindawi.com
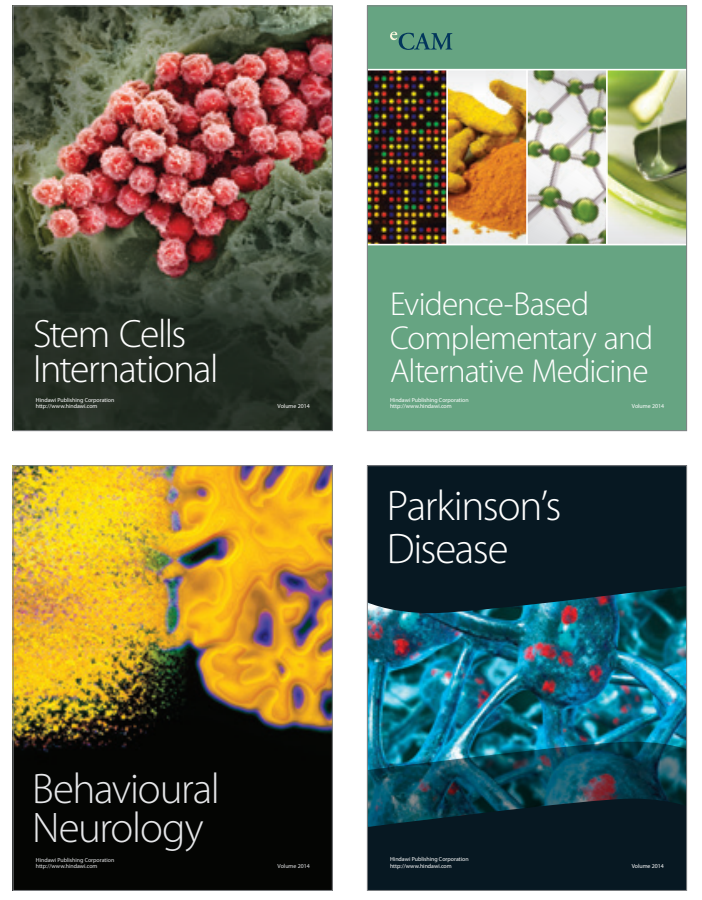
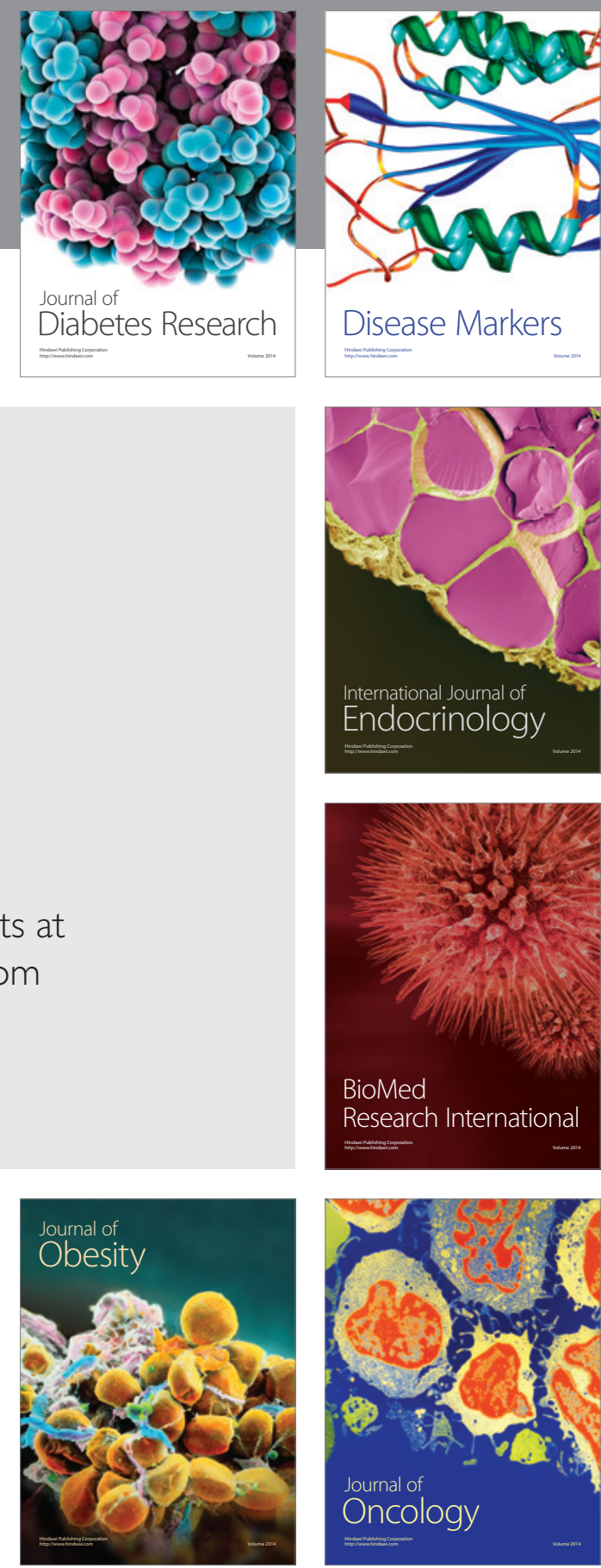

Disease Markers
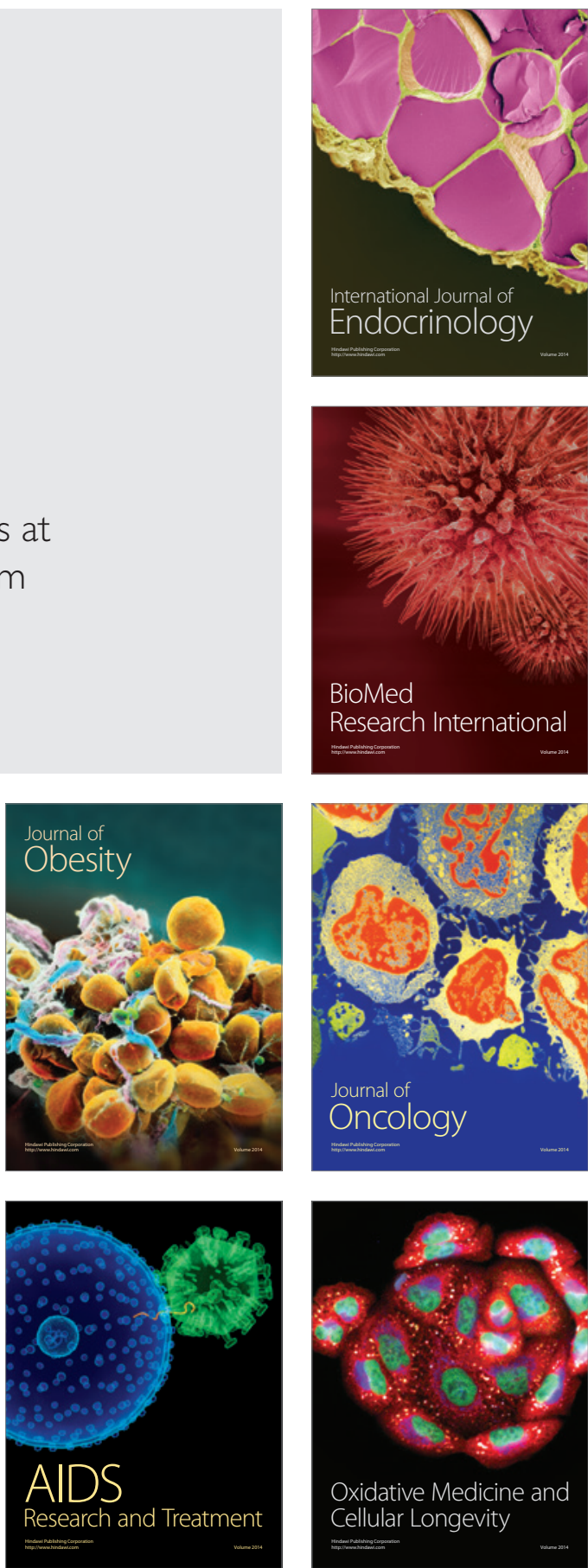